\title{
Experimental Spaces: A Decentred Approach to Planning in High Modernity. Introduction
}

Citation for published version (APA):

Lagendijk, V. C., Couperus, S., \& Van de Grift, L. (2015). Experimental Spaces: A Decentred Approach to Planning in High Modernity. Introduction. Journal of Modern European History, 13(4), 475-479. https://doi.org/10.17104/1611-8944-2015-4-475

Document status and date:

Published: 01/01/2015

DOI:

10.17104/1611-8944-2015-4-475

Document Version:

Publisher's PDF, also known as Version of record

Document license:

Taverne

\section{Please check the document version of this publication:}

- A submitted manuscript is the version of the article upon submission and before peer-review. There can be important differences between the submitted version and the official published version of record.

People interested in the research are advised to contact the author for the final version of the publication, or visit the DOI to the publisher's website.

- The final author version and the galley proof are versions of the publication after peer review.

- The final published version features the final layout of the paper including the volume, issue and page numbers.

Link to publication

\footnotetext{
General rights Owners
rights.

- You may freely distribute the URL identifying the publication in the public portal. please follow below link for the End User Agreement:

www.umlib.nl/taverne-license

Take down policy

If you believe that this document breaches copyright please contact us at:

repository@maastrichtuniversity.nl

providing details and we will investigate your claim.
}

Copyright and moral rights for the publications made accessible in the public portal are retained by the authors and/or other copyright owners and it is a condition of accessing publications that users recognise and abide by the legal requirements associated with these

- Users may download and print one copy of any publication from the public portal for the purpose of private study or research.

- You may not further distribute the material or use it for any profit-making activity or commercial gain

If the publication is distributed under the terms of Article $25 \mathrm{fa}$ of the Dutch Copyright Act, indicated by the "Taverne" license above, 


\title{
Experimental Spaces - \\ Planning in High Modernity
}

\author{
Stefan Couperus, Liesbeth van de Grift, \\ Vincent Lagendijk \\ Experimental Spaces: \\ A Decentred Approach \\ to Planning in High Modernity. \\ Introduction
}

Recent years have seen a sharp increase in the scholarly interest in planning and social engineering, which became widespread in the Western world as well as the colonies and post-colonial states in the age of High Modernity. This age, covering the years between I890 and I970, has been distinguished from other periods, firstly, by the sheer rapidity of economic, social and cultural changes, such as industrialisation, urbanisation, mass emigration, and the «scientification» of society. ${ }^{1}$ What qualifies this period as distinctively modern, however, is that contemporaries themselves were aware that they were entering a «new» era, which offered increased opportunities to shape their own future. ${ }^{2}$ The modern became a category of self-identification, combining a sense of crisis with a strong belief in the possibility to perfect society through interventions. Expectations were high: modernity itself would provide the means, such as scientific knowledge and technological innovations, to channel the sweeping changes and restore a stable order in the post-liberal age.

«Planning» as a concept «embodies the belief that social change can be engineered and directed, produced at will». ${ }^{3}$ Its emergence at the end of the nineteenth century should be attributed to the rise of the modern political economy, which fostered an instrumental attitude towards nature and people. In reaction to the disturbing social consequences produced by laissez-faire capitalism, industrialisation and urbanisation, professionals and experts launched initiatives to improve social conditions, resulting in

1 U. Herbert, «Europe in High Modernity. Reflections on a Theory of the 2oth Century», Journal of Modern European History 5 (2007) 2, 5-2I.

2 L. Raphael (ed.), Theorien und Experimente der Moderne, Cologne 20I2; C. Dipper / L. Raphael, «Raum» in der europäischen Geschichte. Einleitung», Journal of Modern European History 9 (2OII) I, 27-4I; C. Dipper, «Moderne, Version: I.o», Docupedia-Zeitgeschichte, 25.08.2010, URL: http://docupedia.de/zg/Moderne?oldid=84639 (last visited
24 March 20I4); T. Etzemüller (ed.), Die Ordnung der Moderne: Social Engineering im 20. Jahrhundert, Bielefeld 2009.

3 A. Escobar, «Planning», in: W. Sachs (ed.), The Development Dictionary: A Guide to Knowledge as Power, London 2010, I46.

4 Escobar, «Planning», I46-I47. 
the rise of town planning and the incipient welfare state. The state - and at times socially minded industrialists too - became the guarantor of social progress. ${ }^{4}$

The growing belief in the state as the appropriate actor to reconcile various social and economic interests and protect the common good by means of regulatory and disciplinary instruments was the result of shock-like experiences that opened up new realms of state interference. The First World War led to a dramatic increase in planning efforts, initially in order to wage war and regulate the war economy, and then later as a response to the wartime damages. The worldwide economic slump following the crash of the New York stock exchange heralded another episode in large-scale planning. This time it was predicated on the need to secure jobs and stabilise the agricultural sector. ${ }^{5}$ After 1945, the aftermath of war called for new reconstruction initiatives, while planning also became a crucial concept in the attempts to «develop» decolonised states. ${ }^{6}$

Initially, scholarly inquiries into these planning histories stressed the authoritarian and totalitarian polities that provided for such far-reaching interventions. Seminal works, like James Scott's Seeing Like a State, tend to understand planning as being intrinsically linked to a high, even extremist degree of state interference in societal affairs. ${ }^{7}$ Authoritarian state power and a prostrate civil society are seen as the key features of the «failed» grand schemes, which Scott has identified and described. However, already in I987, Detlev Peukert portrayed the Weimar Republic as a «laboratory» of the social. ${ }^{8}$ More recently, scholars have problematized the view on the necessarily authoritarian nature of state planning and have expanded the range of planning histories by looking beyond non-democratic political systems. They convincingly argue that planning and social engineering are trans-ideological historical phenomena, which have occurred in liberal-democratic and authoritarian contexts alike in the age of High Modernity. ${ }^{9}$

This special issue adheres to this reading of planning history: a belief in (state) planning and in the creation of harmonious and coherent social orders emerged on the left as well as the right, under democratic and non-democratic regimes alike. To that, however, this issue adds the plea for a decentred inquiry. In our view, planning historiographies have often adopted a too clear-cut division between planning authorities and

5 See for example E. Hansen, «Depression Decade Crisis: Social Democracy and Planisme in Belgium and the Netherlands, I929-I939", Journal of Contemporary History I6 (I98I) 2, 293-322.

6 The supplement of Past \& Present 2IO (20II) 6 is centred on this theme, as was the workshop «Social Planning in Late Colonial and Post-Colonial Societies» at the German Historical Institute in London in 2013. For a conference report, see: GHIL Bulletin 35 (20I3) 2.

7 J. C. Scott, Seeing Like a State: How Certain Schemes to Improve the Human Condition Have Failed, New Haven, London I998.
8 D. Peukert, Die Weimarer Republik. Krisenjahre der Klassischen Moderne, Frankfurt am Main I987.

9 D. van Laak, «Planung. Geschichte und Gegenwart des Vorgriffs auf die Zukunft», Geschichte und Gesellschaft 34 (2008) 4, 305-326; A. Doering-Manteuffel, «Ordnung jenseits der politischen Systeme: Planung im 20. Jahrhundert», Geschichte und Gesellschaft 34 (2008) 4, 398-406; T. Etzemüller, Die Romantik der Rationalität. Alva \& Gunnar Myrdal - Social Engineering in Schweden, Bielefeld 20Io. 
those being planned in Europe. As a consequence, experts, their plans and their discourses have been at the core of historical analyses, whereas social practices, the level of governance where citizens encounter planning officials, as well as the implementation of plans tend to be of secondary importance. As the contributions in this special issue reveal, such a decentred, governance-focused perspective forces us to thoroughly reconsider notions of the state, the planning agents as well as the planning recipients.

This issue is composed of contributions by scholars who have recently probed into a variety of spaces in need of a system of governance that would structure and order the entity at issue. Three important differences with the more traditional literature on planning can be noted. Firstly, our contributors shift the focus away from large-scale transformations and onto more medium-sized if not micro-locales of planning. This change of scale puts new actors into the spotlight, including non-state planning elites as well as those being planned for. Secondly, by doing so, we are able to go beyond the planners' discourse and investigate the practices of planning. Finally, this approach enables us to demonstrate the dynamic nature of most planning exercises.

\section{The Research Agenda}

This special issue, thus, proposes a historical approach to social planning that differs to a large extent from the tenets in the recent historiography on social planning and engineering. Firstly, it contends that a decentred, localist inquiry sheds light on the social dynamism, which informs planning practices and discourses alike. Therefore, by moving away from taking the state as the sole framework of analysis, we can critically assess the social interactions between groups of people, who have often been regarded separately in state-focused analyses. Secondly, the contributions interpret the relations between the planners and the planned as intrinsically unsettled. Consequently, planning as practice is no longer primarily interpreted as a linear process. Planning does not uninterruptedly lead from the conception of the plan to its implementation and execution. Instead, the articles view planning practices as capricious undertakings, which are subject to re-interpretations, re-adjustments, re-configurations, restrictions, enlargements, (un)intended feedback mechanisms and deadlocks at various stages of conception, negotiation and implementation.

Evidently, these conceptual orientations are not innovative in their own right. Many aspects of them may even be found in the existing planning historiography. However, taken together, these three orientations encapsulate a historical, localist understanding of «planning by doing», which avoids some of the fallacies in many planning histories.

To begin with, the state - or related planning agencies or expert groups - is not represented as a monolithic black box that superimposes planning agendas on people. In contrast, this issue depicts the specific agency of state actors, agents, experts, personnel and officials, who engage and participate in a particular planning practice. The same applies to civil society. Voluntary associations and organised groups are not mainly seen as the (often unhappy) recipients of planning, but its representatives are 
also planning actors in their own right. Moreover, state actors are not seen as planning advocates per se, whereas civil society representatives do not exclusively display univocal protests to planning. State actors might consider rejecting intervention by planning, while agents of civil society might join the planning authority they are confronted with, or develop planning schemes themselves.

Our insistence on planning by doing allows for an in-depth assessment of the experimental nature of planning. To be sure, in line with the historical actors themselves, we cannot regard specific plans as «experiments», since experts and planners always held strong convictions on the effects of their interventions and on their expected outcomes. At the same time, their final aims of planning were never narrowly defined outcomes or blueprints, but more holistically phrased objectives, such as equilibrium, harmony, affluence, organic order, and modernity.

The road towards such objectives was not short and straight, but a rather long and winding one - which might have even ended in a cul-de-sac. In order to keep their eyes on the ball, experts and planners thus had to adjust and realign - practically and discursively. Moreover, in some instances, the composition of planning elites was subject to changes. This is what we mean by «planning by doing». As a consequence of this clash with reality and because of the holistic aims, planning has to be regarded as an openended process.

In general terms, this special issue critically examines the social interactions at various decentralised scales and spaces (i.e. transport hubs, model villages, community centres, urban neighbourhoods). The concept of «space» refers to the local scale of analysis, but it also indicates the impact of spatial settings on social practices. In turn, then, these interactions reveal a highly dynamic set of (discursive) practices in which (pre-)determined and (self-)defined roles of historical actors, whether planners, experts or citizens, are all but fixed. This amounts to three focal points, which lie at the heart of this issue's articles: the relation between planning discourse and social practice; the contested - and re-adjustable - ambitions and goals in social planning; and the significance of agency of a wide range of historical actors in planning practices.

\section{The Agenda in Practice}

Our contributions reveal a complex duality between expert discourse and planning practice. The case of the Peckham Health Centre, examined by David Kuchenbuch, displays this complexity par excellence. By solely focusing on the scientific discourse of medical experts, one gains a highly structured account of the social experiments conducted at the centre. However, a critical assessment of the practices and the social interactions at the centre, as conducted by Kuchenbuch, discloses a much more self-reflective and reciprocal perception of social realities by the experts in charge.

Additionally, our contributions demonstrate that the practice of planning often had only little to do with the imposition of rigid, dogmatic blueprints on society. Anticipated outcomes tended to be couched in abstract terms, such as «equilibrium» (be- 
tween the individual and the collective), «order» (as opposed to free-reigning market forces), and «community» (as opposed to the alleged «atomisation» of society). This is, in part, an expression of the particular local context of the studies examined here. Although the planners might have expected these schemes to have an impact on society at large, their schemes were never part of an overarching master narrative of planning. In her article, Anette Schlimm analyses experts engaged in setting up a system of regional milk distribution in Cornwall. They understood their task to be specifically regional in nature and did not aim for an all-encompassing system of food distribution on a national or even international scale. In a similar vein, Stefan Couperus' article on the reconstruction of blitzed cities highlights ambitious small-scale housing and community building initiatives. Stemming from the voluntary sector, these initiatives sought to improve the urban conditions not by adhering to the official urban reconstruction schemes, but, alternatively, by departing from the grassroots level.

Thirdly, our contributors analyse the relationship between planners and planned. As a result of a decentred approach the distance between both decreases, as planning officials and citizens become part of the same analytical framework in which the plan is re-adjusted as a result of the agencies of both planners and the planned. This is demonstrated by Anette Schlimm's article, which offers the most evident example of the modification of a plan by its users. Raluca Musat, who in her article examines the widespread phenomenon of model villages in interwar Romania, Turkey and Italy, shows that even authoritarian state authorities, such as the royal dictatorship of Carol II in Romania, were unable to keep their subjects from undermining the modernising schemes by acting in opposition to the project's stated aims. In the article by David Kuchenbuch, the interaction is carried to its most extreme, when the distinction between experts and visitors of the centre seems to dissolve completely. In those instances, the experts seem to regard themselves as parts of the planned communities at hand.

We hope that this effort will help set a new research agenda for historians interested in planning, with a focus on decentred practices and discourses of planning in the twentieth century. 


\section{A Decentred Approach to Planning in High Modernity \\ Experimental Spaces: \\ A Decentred Approach to Planning in High Modernity. \\ Introduction}

Recent years have seen a sharp increase in the scholarly interest in planning and social engineering, which became widespread in the Western world as well as the colonies and post-colonial states in the age of High Modernity. This special issue shows that a belief in (state) planning and in the creation of coherent social orders emerged on the left as well as the right, under democratic and non-democratic regimes alike. Moreover, it argues that a decentered, governance-focused approach to planning, which takes into account not only expert discourses but also practices, forces us to thoroughly reconsider notions of the state, the planning agents as well as the planning recipients.

Stefan Couperus

University of Groningen Department of European Languages and Cultures Oude Kijk in 't Jatstraat 26 NL-9712 EK Groningen, the Netherlands e-mail:s.couperus@rug.nl

Liesbeth van de Grift

Utrecht University Department of History and Art History Drift 6

NL-3512 BS Utrecht e-mail: l.vandegrift@uu.nl

Vincent Lagendijk Maastricht University History Department Grote Gracht 76, PO Box 616 NL-6200MD Maastricht e-mail: vincent.lagendijk@maastrichtuniversity.nl 


\title{
David Kuchenbuch
}

\author{
A Laboratory of Anarchy? \\ The London Pioneer Health Centre \\ and the Experimentalization of the Social, \\ I935-I950
}

In 2007, in an article in the Guardian, journalist Jonathan Freedland observed a recent trend in British politics: According to him, politicians were embracing new ideas about welfare policy and the empowerment of local communities. ${ }^{1}$ Providing them with further inspiration Freedland did not point to contemporary projects. Instead, he recommended talking «to Pam about pre-war Peckham». Pam Elven of Peckham - a neighbourhood in the London borough of Southwark - he claimed, could tell cabinet ministers more about a project she had participated in some 70 years earlier: the Peckham experiment. Freedland was referring to the Pioneer Health Centre (PHC), established in I935: a health and leisure club for working-class families. He wrote that this Centre was to an astonishing degree run by members of the local community themselves. There were no lectures and few rules. Whenever they chose to do so, the Centre members could use the swimming pool, the library, and sports equipment. And whenever they wanted, they could ask the two doctors who had initiated the experiment for medical advice. Meanwhile, the physicians Georg Scott Williamson (I884-I953) and Innes Hope Pearse (1889-I978) were silently monitoring the environment they had helped create. The freedom of the Centre, they found, had resulted in a significant increase in the members' fitness, and, more importantly, it had fostered the growth of an active community.

Freedland's historical inspiration is not as far-fetched as it might seem. In British progressive discourse the Peckham Centre has resurfaced many times since its closure in I950. Especially in the late I980s, it was propagated as an approach to health promotion consistent with pluralist claims for political participation. ${ }^{2}$ Even before that, educators, architects and public intellectuals, such as Aldous Huxley, had held that «Peckham» demonstrated how individuals from all kinds of social backgrounds could be

1 J. Freedland, «Ministers seeking inspiration should talk to Pam about pre-war Peckham», in: Guardian, 31.10.2007.

2 K. Barlow, Recognising Health, London I988; A. ScottSamuel, Total Participation, Total Health: Reinvent- ing the Peckham Health Centre for the 1990s, Edinburgh I990. Today, the Pioneer Health Foundation is preserving the legacy of the PHC: http://thephf. org/. 
stimulated into activity, while keeping state control (and spending) at a minimum. ${ }^{3}$ In the mid-I960s, the Peckham experiment actually embodied an almost utopian dream: British anarchists like Colin Ward viewed it as scientific proof that a peaceful society, devoid of institutions and consisting of individuals eager to cooperate while following their own paths to fulfilment, was indeed possible. «Peckham», to Ward, seemed like «a laboratory of anarchy». ${ }^{4}$

It is the aim of this article to reconstruct the experiment and, in doing so, to question the narratives and interpretations introduced above. In my article, I will loosely follow a chronology. Firstly, I will consider the original aims of the Pioneer Health Centre as well as the context of its establishment, which dates back to the I920s. As a close look at its archival records reveals, ${ }^{5}$ and contrary to the familiar narrative, the PHC did not start off as a research station designed to study social self-organization (I.). In fact, it owed more to Victorian traditions of social work than to anarchist visions of empowered communities. It was also hardly as original as some of its recent supporters claim. This presents us with an interesting question: How, under what circumstances, and when, did the Pioneer Health Centre turn into the «Peckham experiment», which still captivates the imagination of political commentators in the twenty-first century?

To answer this question, a second section will explain the rather sweeping re-interpretations of the Centre by its founders between I935 and I939 (2.). It will show that both the relative freedom the users enjoyed in the Centre and the notion of social experimentation only gradually evolved during the late I930s. As the Peckham doctors struggled to adapt a biological epistemology to the chaotic reality in the Centre, they developed an early type of participant observation. However, the scientists' insights regarding the merits of social self-organization started to reverberate in the laboratory. Many Centre members began to invest their individual development with meaning based on the scientists' evolving theories (3.). As a third section will show, the methodological blind spots that resulted from this rather precarious experimental setting proved disastrous in the late I940s, when the PHC had to apply for outside funding. Pearse and Scott Williamsons, however, attributed the eventual closing of the Centre to

3 A. Huxley, Brave New World Revisited, New York I958, I43. Praise for the PHC can be found, for instance, in L. Moholy-Nagy, Vision in Motion, Chicago I947, 359; L. Haworth, The Good City, Bloom ington I963, I26-I28; C. Alexander, A Pattern Language. Towns. Buildings. Construction, New York I977, 252-255; and L. Berg, «Moving towards Self Government», in: J. Hall (ed.), Children's Rights. Towards the Liberation of the Child, London I972, 8-53. The experiment even left a mark on popular culture: It plays an important role in Piers Anthony's I969 science-fiction novel «Macroscope».

4 C. Ward, «A Laboratory of Anarchy». A Comparative Anthology», in: Anarchy 6 (I966), 56-6I. On anarchist appropriations of the Centre: E. Charkin, «Building the Natural Society of the Future»: The Peckham Experiment (I943) as an Anarchist Account of Childhood and Education», in: Paedagogica Historica 50 (20I4), 4I4-432.

5 Research on the PHC has not yet fully utilized the wealth of primary sources in the London Wellcome Library for the History of Medicine (see L. A. Hall, «The Archives of the Pioneer Health Centre, Peckham, in the Wellcome Library», in: Social History of Medicine I4 (200I), 525-538), as well as additional material that can be found in the National Archives, Kew, and the Archives of the London School of Economics. 
the emerging welfare state's hostility towards individual freedom and family life. In the concluding section I will show how «Peckham» can serve as a case study in several respects (4.).

\section{From Social Work to Social Experimentation}

The Pioneer Health Centre was established as a charity based on bio-political concerns. In I926, a first Centre opened its doors for the Peckham residents on Queen's road, some blocks away from the later, much larger Centre. The project was initiated by a group of wealthy philanthropists, who had a clearly defined goal consistent with the international discourse on eugenics at the time. ${ }^{6}$ The Centre was meant to raise the physical condition of the urban working-class as well as educate on hygiene, family planning and contraceptives. For this reason, it was organised along the lines of a family club. It had a medical examination room, but it also came equipped with board games, tools (for the men) and sewing machines (for the women). In this way, the founders hoped to attract people by appealing to their «inherent desire for some constructive hobby», as they wrote in a 1925 manifesto. ${ }^{7}$ They were convinced that they could best distribute information on matters of health by addressing the family as a whole. Generally, close contact between physicians and ordinary people seemed imperative, since it seemed to be the only method that would increase the people's responsibility for their own bodies and those of their potential offspring: «We [...] must implant in their minds how essential it is for them to be in a fit state themselves before they contemplate the creation of life.» ${ }^{8}$

Clearly, the adjective «pioneer» in Pioneer Health Centre is misleading, even with regards to the first, smaller Centre. As research on social hygiene in Britain has shown, the idea to increase the health of the nation and thus gain in national efficiency was rather undisputed within the British elites after World War I. In fact, the need to improve the physical «quality» of the lower classes had been the subject of intense political debates since the Second Boer War (1899-1902). Consequently, a first compulsory (if rudimentary) health insurance for workers (in I9II) and the Ministry of Health (in I9I9) were established. ${ }^{9}$ Furthermore, even the specific approach to social work, chosen

6 Among them were heirs to companies like Sainsbury's and what was to become Unilever. The Hon Mrs Ewen Montagu recollects the origins of the Pioneer Health Centre, I998, Wellcome Library (WL), SA/PHC/B.I/I/I. See, for instance: S. Kühl, For the Betterment of the Race. The Rise and Fall of the International Movement for Eugenics and Racial Hygiene, New York 2013, and M. Turda, Modernism and Eugenics, Houndmills, New York $20 \mathrm{or}$.

7 Notes re Pilot Scheme Plans, I925, WL, SA/PHC/ B.I/I/2, 2.

8 Ibid., 2.
9 See A. Beach, «Potential for Participation: Health Centres and the Idea of Citizenship c. I920-I940», in C. Lawrence / A. Mayer (eds.), Regenerating England. Science, Medicine and Culture in Interwar-Britain, London 2000, 203-230; I. Zweiniger-Bargielowska, Managing the Body. Beauty, Health, and Fitness in Britain 1880-1939, Oxford 2010; as well as G. Jones, Social Hygiene in Twentieth Century Britain, Beckenham I986 (who mentions the PHC in passing: 9) and V. Berridge, Health and Society in Britain since 1939, Cambridge I999. 
by the Peckham founders in order to overcome the perceived medico-social crisis, was dated by the standards of the I92os. In contrast to what it later came to stand for, the main objective of «Peckham» at this time was to implant in the «deserving poor» a sense of responsibility through neighbourly contacts with their social «betters». The Centre in Peckham might actually be considered a late-comer amongst a large number of elite attempts to «improve» the lower classes, not least by establishing institutions with rather experimental approaches: When compared, for instance, to mid-I930s' projects like the self-governing, anti-authoritarian «Q-Camps» for delinquent boys in Hawkspur, Essex ${ }^{10}$ the Pioneer Health Centre actually bears more resemblance to the settlement houses established in the poor quarters of large cities in the late I9th century, such as Toynbee Hall in London and Hull House in Chicago. ${ }^{11}$ Similar to the PHC, volunteer work in these institutions focussed on individuals and their families in order to assist with self-improvement. ${ }^{12}$ More importantly, at the turn of the century, influential associations, such as the Charity Organization Society, endorsed such personal approaches because, to them, both anonymous charity and financial redistribution by state agencies seemed only to foster dependency and passivity on the receiving end $^{13}$ - a belief that the founders of the Peckham-Centre shared. When the PHC was established, progressive reformers like Beatrice and Sidney Webb had in fact long attacked such reasoning as ignorant of the structural rather than moral basis of social problems in what was essentially an unjust society. ${ }^{14}$

What, however, made «Peckham» stand out from the large number of contemporary single-issue voluntary institutions was the intention to scientifically survey the health-effects of individual medical advice within a working-class community. The evaluation of the members' health showed that the project was quite successful in this regard. ${ }^{15}$ The first medical report of 1927 claimed that the member families were healthier and better informed about hygiene, family planning and even nutrition. They were generally taking better care of themselves and even their social life had been enriched. The Centre was so popular that membership numbers soon began to outgrow its capacity. In 1929, the institution was closed down, and planning for a much larger building began.

10 D. W. Wills, The Hawkspur Experiment. An informa account of the training of wayward adolescents, London I967 [I94I]. Nevertheless, in retrospect, «Hawkspur» and «Peckham» were often regarded as close relatives: C. Ward, «Anarchism as a Theory of Organization», in: L. Kirmerman / L. Perry (eds.), Patterns of Anarchy, New York I966, 34935 I.

11 See N. Scotland, Squires in the Slums: Settlements and Missions in Late-Victorian London, London, New York 2007; R. Crocker, Social Work and Socia Order: The Settlement Movement in Two Industrial Cities, 1889-1930, Urbana, Chicago I992.
12 Still fascinating on ideologies of self-improvement in Victorian England: P. Joyce, Democratic Subjects. The Self and the Social in Nineteenth-century England, Cambridge, New York I994.

13 R. Humphreys, Poor Relief and Charity 1869-1945. The London Charity Organization Society, Houndmills, New York 200I.

14 See the Minority Report of the Poor Law Commission Part I: The Break-Up of the Poor Law. Edited with an Introduction by Sidney and Beatrice Webb, Clifton I979 [I909].

15 Annual Report I927, WL, SA/PHC/A.2/2. 
Two years later, capitalising on this initial success while raising funds for the new project, Pearse and Scott Williamson published a first account of their work in Peckham, titled The Case for Action. Both doctors had originally only been hired to conduct the routine medical examinations. But now they were increasingly monopolising the Centre's findings. Pearse and Scott Williamson had begun to conceive of the new Centre as an asset that would allow for the long-term observation of healthy behaviour in a «natural» setting. Crucially, in keeping with the personal approach of the first PHC, in their book, they considered themselves to be «knowledgeable friend[s]» of the future Centre members, rather than distant experts. ${ }^{16}$ Yet, in stark contrast to retrospective accounts, the social activities they envisaged in I93I were still a far cry from being selforganized. Pearse and Scott Williamson pointed out that individuals would have to be «drafted by medical prescription» to the activities in the Centre. Clearly, the doctors were rather suspicious of the average «working man»: «[T]he intramural clubs [...] will be at the same time a source of disciplined development and not merely a way of whiling away time.» ${ }^{17}$

In May 1935, the new purpose-built health centre opened its doors on St Mary's Road, Peckham (Figure I). Architect-engineer William Owen had designed a transparent, stripped-down building, which quickly became an icon of British modernism. ${ }^{18}$ The building housed special laboratories for the doctors; for the users, it featured a

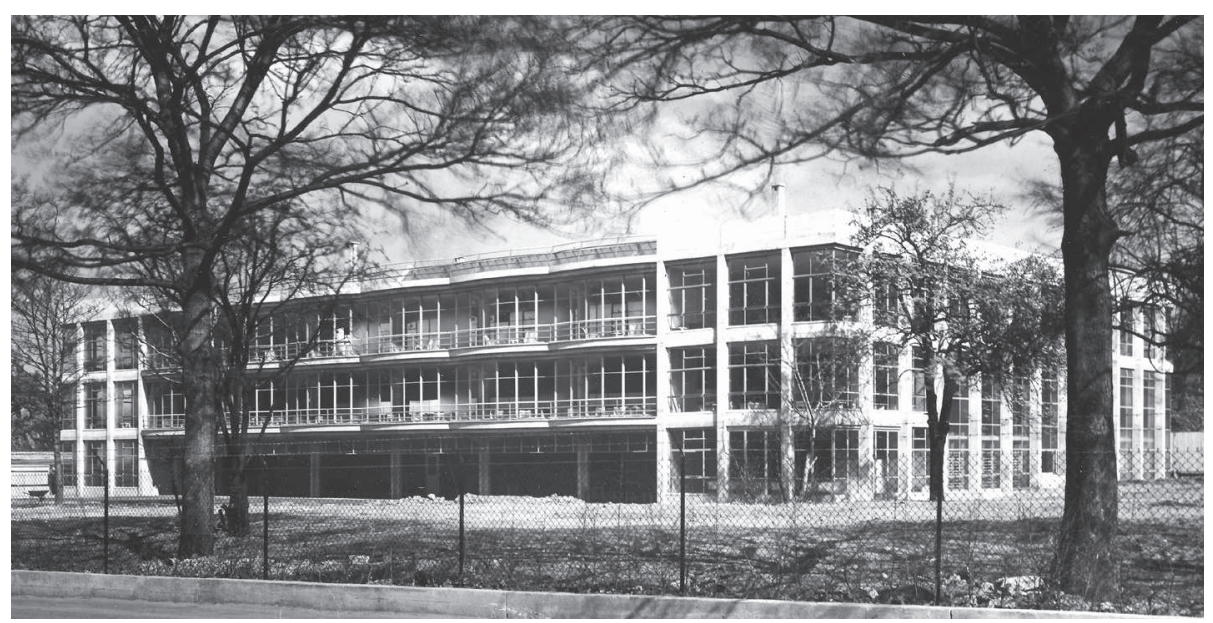

1: Bildunterschrift liefern bitte und Source

Source:

16 G. Scott Williamson / I. H. Pearse, The Case for Action. A Survey of Everyday Life under Modern Industrial Conditions, with Special Reference to the Question of Health, London $1938, \mathrm{I} 36$.

17 Ibid., I37.
18 See P. Gruffudd, «Science and the Stuff of Life»: Modernist Health Centres in I930's London», in: Journal of Historical Geography 27 (200I), 395-4I6; E. Darling, Reforming Britain: Narratives of Modernity before Reconstruction, London 2006. 
large swimming pool, a self-service-cafeteria and a gymnasium. There were toys, tools, billiard tables, a small stage, a library and a day nursery. Resembling a leisure Centre rather than a polyclinic, the structure was designed to be used by up to 2000 families. The residents of Peckham were invited to join the Centre after paying a weekly subscription fee. There were two preconditions, however. For one, it was only possible to join as a family. Furthermore, every family had to go through a health inspection upon joining and then again once every year. During this check-up, the individual's health status was assessed and then discussed in a family consultation.

The events that followed by far surpassed the doctors' expectations, at least according to their bestselling, internationally acclaimed I943 book The Peckham Experiment. A Study in the Living Structure of Society. In this book, Pearse and her assistant Lucy Crocker claimed that, after some initial chaos, a highly harmonic order had emerged. «In the Centre», Pearse remarked, «the visitor is generally very surprised that what he sees before him is spontaneous action and not the result of program, persuasion or regulation..$^{19}$ Apparently, people were making extensive use of the Centre and had formed clubs of their own. Individuals who had been neighbours for years without ever talking to each other were now sharing their knowledge, some of it only recently acquired via the medical staff. As a result, they were exhibiting a much more pro-active lifestyle.

In their book, Pearse and Crocker drew several conclusions. First of all, they found that it was imperative to review what they painted as top-down interventionism prevalent in contemporary public health policy - rather unjustly, given the heterogeneity of approaches to preventive medicine in inter-war Britain. To the authors, ensuring the diffusion of medical knowledge amongst the members of a community was the most efficient way to cultivate responsibility. But more importantly, a milieu rich in social stimuli would also free biological potentials otherwise untapped in modern society. Pearse and Crocker were sceptical of more radical attempts at «hereditary improvement» - to them, eugenics amounted to dabbling in matters better left to nature. ${ }^{20}$ They favoured the metaphor of nurture, thus merging the semantic fields of physiological and educational «intake». To the Peckham-doctors, all people, irrespective of their hereditary outfit, would (and should) continue to grow as individuals, much like an embryo in the womb, when enabled to use resources provided by their social environment. Crucially, for the doctors, the effect of such enabling circumstances - «positive health» as they liked to call it - could not be defined as the mere absence of illness. On the contrary, positive health encompassed qualities of its own, such as emotional selfrealization and the ability to stimulate social activity in others.

19 I. H. Pearse / L. Crocker, The Peckham Experiment. A Study in the Living Structure of Society, London I943, I28. 
The way Pearse and Crocker were substantiating their theories, however, was unusual, yet comprehensive. In their book, they were utilizing a wide range of narrative techniques, as well as photographs. The medical results were introduced by a rather conventional table, which revealed the quantity of the disorders discovered among the Peckham population. Most chapters, however, presented the readers with a more allegorical narrative. Throughout much of the book, Pearse and Crocker were describing what they perceived as a natural cycle of human reproduction, a pattern supposedly derived from many examples in the Centre. This narrative amounted to a rather flowery tale of happy family life within a community of friends, all eager to share their knowledge, collectively overcoming ill-health, isolation and passivity, as well as producing altruistic, yet determined offspring. Significantly, statistical data played only a minor role in validating such social effects - only in one instance did Pearse and Crocker rely on quantification: They presented the case of an eleven-year-old boy, who, after a turbulent phase of testing out all the facilities the Centre offered, had gradually discovered his natural talents. An individual pattern had emerged, which the authors even depicted in a diagram. Although they produced little evidence for this claim, Pearse and Crocker held that such individual growth was prerequisite for the collective progress they were witnessing. The very «diversity of individual specific actions», they claimed, resulted in an «order arising out of the capacity [...] to respond to the total situation. ${ }^{21}$ To Pearse and Crocker, social self-organisation and individual responsibility were interdependent factors in establishing what they perceived as a biologically sound societal order. Strikingly, they were by now defining «responsability [sic] ${ }^{22}$ as an instinct - an ability to respond - rather than an ethical category. To the Peckham scientists, responsibility basically amounted to a susceptibility to the «mutual synthesis» within a community of families.

\section{Evolutionary Thinking and Social «Chaos»}

Clearly, when Pearse and Crocker began writing The Peckham Experiment in 1939, they had lost interest in the reformist objectives of the original Centre. To understand how this change came about, two factors have to be considered. For one, in the early I930s, the Peckham doctors, much like British intellectual culture in general, had become infatuated with new concepts of social evolution. These ideas, secondly, provided the doctors with an epistemic framework much needed in I935, when the Centre was running into unexpected difficulties.

Almost all recent accounts of the Peckham experiment ignore the fact that Pearse and Scott Williamson saw their project as a biological rather than a social experiment. They considered themselves biologists, not sociologists or physicians. This self-image must be put into historical context. In the early I930s, many physicians endorsed a certain holism in medicine. This can be seen as a defence strategy against increasing 
specialisation in the medical profession, and more generally, as a reaction to a perceived tendency towards rationalisation in the modern world. ${ }^{23}$ But such holism also directed scientific interest towards environmental aspects of organic functions, a view which was further underlined by advances in endocrinology. Julian Huxley, for instance - he was later to become a member of the PHC's advisory board - conducted a famous experiment that elucidated the role of hormones in the development of organisms. Concepts of communicative interaction between the organism and its surroundings, which enabled the body to maintain homeostasis, began to affect the understanding of social processes as well. ${ }^{24}$ Not least since the emphasis on the environment corresponded to a new interpretation of evolution as a cooperative process, put forward, again, by Huxley and other so-called Scientific Humanists. To this influential group of scholars, social interaction by state-forming species seemed to provide models that could be applied to human organization, too. Incidentally, such reasoning - notwithstanding the Scientific Humanists' progressivism - legitimized the extraordinary position held by upper-class academics. More «developed» personalities, it seemed, were entitled to leadership in society. By virtue of their refined culture, they were fit to realise their communities' potential. ${ }^{25}$ Widespread as they were within British discourses on social reform, these new evolutionary ideas fell on particularly fertile ground in the minds of Pearse and Scott Williamson. Both had been conducting research into the thyroid gland and its hormones while planning the second Centre. ${ }^{26}$ When the PHC opened its doors, the doctors increasingly regarded it as an unprecedented laboratory, within which they could explore social evolution in real life. Crucially, rather than coldly investigating this process from a distance, they were ready to cultivate the growth of a community they were themselves part of. ${ }^{27}$ In fact, it seemed imperative to walk the thin line between over-integration and excessive specialisation, as both extremes could result in stagnation of human development because of a lack of reciprocal stimulation.

However, another, more prosaic factor seems also to have played a role in furthering the Peckham scientists' interest in freely unfolding socio-biological processes. While money is rarely mentioned in the official publications on the PHC, the archival records are full of documents relating to the economy of the Centre. They leave no doubt that even in its mid-I930s' incarnation, one of the project's main objectives had

23 C. Lawrence / G. Weisz, «Medical Holism: The Context», in: idem. (eds.), Greater than the Parts. Holism in Biomedicine, 1920-1950, New York I998, I-22.

24 See J. Tanner, «Weisheit des Körpers» und soziale Homöostase. Physiologie und das Konzept der Selbstregulation», in: P. Sarasin / J. Tanner, (eds.), Physiologie und industrielle Gesellschaft. Studien zur Verwissenschaftlichung des Körpers im 19. und 20. Jahrhundert, Frankfurt a. M. I998, I29-169.
25 R. Smith, «Biology and Values in Interwar Britain: C. S. Sherrington, Julian Huxley and the Vision of Progress», in: Past Q Present I78 (2003), 210-242; M. Sommer, «Die Biologie der Demokratie im Wissenschaftlichen Humanismus», in: M. Hagner (ed.), Wissenschaft und Demokratie, Frankfurt a. M. 20I2, 5I-69.

26 See WL, SA/PHC/F.I7/2.

27 First eight months. May-Dec I935, WL, SA/PHC/ B. $3 / 8 /$ I, IO. 
been economic: Could an institution like the PHC be maintained entirely through members' subscriptions? Clearly, another Victorian idea haunted the PHC. Its original supporters were convinced that people would react more readily to welfare work if they were paying for it. Assuming that many Peckham residents would happily pay their weekly subscription, all financial budgeting for the larger Centre had been calculated on the basis of weekly payments by about 2000 families. However, membership numbers in the second Centre never rose above 700 families. Thus the PHC was never able to support itself. And in light of its constant financial crisis, the unexpected difficulties that it faced right after its opening appeared to be especially threatening to the Centre's existence. During the first months, equipment was stolen, glass panes were smeared, and children were «curling» with the heavy glass ashtrays while their parents were dully sipping beer in the dirty cafeteria. «Chaos», Pearse would remember later, «raged for many months.» ${ }^{28}$ Much to the frustration of the staff, they had to «walk and walk and walk round and up and down the building - watching the destruction, powerless to stop it [...]. «Can't you do something to stop these children breaking everything up?> The answer of course was that we could, but at the risk of driving them out.» ${ }^{29}$

Fatally, the staff suspected that rumours, which had spread in the neighbourhood about the chaos in the Centre, were preventing other Peckham residents from joining it. Adding to the general confusion, some of the gym teachers had begun to enforce order themselves by issuing suspensions. But these suspensions were immediately revoked by the directors, further undermining the teachers' authority. ${ }^{30}$ Clearly, in trying to prove the hypothesis that knowledge was best informally communicated within a community, the medical staff was keen not to «contaminate» the laboratory from the very start. They resisted their urge to intervene when confronted with untreated medical conditions and unreasonable behaviour. ${ }^{31}$ Additionally, the staff soon realized that the activities they had organized along traditional lines - with fixed timetables and instructors evaluating individual progress - failed to attract the people of Peckham. There was no way to pressure the members into joining swimming or fitness classes. Eventually, after consulting some of the members, tickets for activities were distributed, enabling individuals to use the facilities autonomously. The ticket-system had the added advantage of allowing for a collection of data about the users' actions.

On all accounts, the chaos disappeared after some months, as members began to organize their own activities. In 1938, the two directors published a preliminary report on their observations: Biologists in Search of Material. In contrast to The Peckham Experiment, this short book has largely been forgotten today. «Individuals», the doctors had learned, «resent or fail to show any interest in anything initially presented to them through discipline, regulation or instruction which is another aspect of author-

28 Pearse, The Quality of Life, 26.

29 L. Pearce [née Crocker], Chaos in the Centre. Notes on Children (1935-36), I970, WL, SA/PHC/E.I5/I, 2.
30 Ibid., 3.

31 See Letters, I935-I936, WL, SA/PHC/B.3/7. 
ity.» ${ }^{32}$ They thus concluded: «It seems that <a sort of anarchy is the first condition in any experiment in human applied biology.» ${ }^{33}$ Even in the leaflets that the directors kept sending out to potential member families in the neighbourhood, they had begun to point to the participation in the Centre as one of its attractive features: «You have the chance to co-operate in this great experiment [...], to make it grow in the right way. Why not come in and see what you're missing?» ${ }^{34}$ Membership numbers did not rise substantially, however. Nevertheless, such promises were impossible to revoke - even less so as Scott Williamson had begun to interpret the order in the Centre as the result of a process of biological integration. In line with this interpretation, he began to share even his most daring hypotheses about their behaviour with the members. In one of his regular «Sunday meetings» in 1936 he proclaimed: «[I]n joining the Centre you have become serious partners in a team of research workers. [...] Somehow or other you have to try and become an active member of the team and being so are as responsible as any other part of a whole body.» ${ }^{35} \mathrm{~A}$ «strange laboratory» had emerged, ${ }^{36}$ not least due to William Owen's architecture. The open plan of the building allowed for constant movement and great visual transparency. The swimming pool, for instance, was separated from the cafeteria only by glass partitions. This enabled the scientists to easily observe the members. Pearse and Crocker also claimed that being visually confronted with the activities of others spurred the members to action. However, the transparency was two-sided, as, by the late I930s, the doctors themselves suggested. Apparently, they now conceived of their work as a kind of participant observation, even though they never explicitly used the term. The retrospective «experimentalization» of the PHC the staff spoke of an «experiment» much more frequently in the late I930s - seems to have helped justify this rather precarious way of gathering information. This is evident in a 1938 manuscript by Jack Donaldson entitled What do we mean by calling it an experiment?: «Scientifically, the experiment can be described as the attempt to provide a suitable environment for the family, and then to see and record what happens. The «suitable environment is of course experimental in itself, and has continually to modified [sic] by experience. [...] [I]t is not wished to produce certain effects in the people belonging to the Centre, but rather to see what effects, if any, will emerge. The staff members have to guard themselves continually against tendentiousness.» ${ }^{37}$

32 G. Scott Williamson, George / I. Pearse, Biologists in Search of Material. An Interim Report on the Work of the Pioneer Health Centre, Peckham, London I938, 40 .

33 Ibid., 38.

34 The Centre, St Mary's Road, Peckham, SEI5 [app. I937], WL, SA/PHC/B.3/22/I.

35 Typescript [September I936], WL, SA/PHC/B.3a/ 9, I. Strikingly, in later lectures, Scott Williamson presented the scientist as the spearhead of human evolution, encouraging his audience to conduct research of their own - by finding out more about their own dormant abilities. Typescript [1936/ I937], WL, SA/PHC/B.3/9.

36 Pearse / Crocker, The Peckham Experiment, 48.

37 J. Donaldson, Scheme A. The Pioneer Health Centre is a biological experiment, 1937-1938, Wl, SA/PHC/ B.3/10/2, 5. Donaldson had made the building of the Centre possible by donating half his inheritance and since become an engaged member of staff. 


\section{The «Guinea Pigs» and the «Passing of Peckham»}

A year later, in I939, the Centre was closed down. The authorities had decided that it was unsafe to use a glass building located closely to potential air-raid targets in the London Docks. Pearse and Crocker began writing The Peckham Experiment. When they had finished the book, as indicated, much of today's narrative on «Peckham» had evolved. Never shy of generalizations, the authors now claimed that «at the end of four years there is little to distinguish members from staff in the social interplay of the Centre. The whole medium is social - Science socialised. The Centre has, in fact, shown itself to be a potent mechanism for the 〈democratisation> of knowledge and action.» ${ }^{38}$ As progressive as this might sound to us, as I have demonstrated, this democratisation had only been a by-product of the original project. Forced to experiment with the organisation of the Centre, the medical directors had «discovered» the ability of the Peckham residents to act on their own impulse, without assistance. Soon, this ability became much more fascinating to the scientists than the mere effects of healthy living they had set out to study.

But how then did the members themselves appropriate the experiment? Evidently, the Centre was very popular with those who used it (if not with the majority of Peckham's residents). At least, this is the impression conveyed by Being Me and Also Us, an anthology on the experiment, edited in I989 by Alison Stallibrass, an assistant to Crocker in the I940s, which features several members' memoirs. In fact, the former members Stallibrass had interviewed were full of praise for the Centre, most of them pointed out how it had changed their lives for the better. But interestingly, in looking back, the interviewees were clearly framing their experiences in terms provided by Scott Williamsons and Pearse. ${ }^{39}$ This points to a difficulty familiar to many oral historians: The members knew what they were talking about and what was expected of them - in the early I980s, when the interviews were conducted, the books on the experiment were easily accessible..$^{40}$ More problematically, a second glance reveals that many of the interviewees were involved in attempts at re-establishing the Centre during these years. Strikingly, other interviews preserved in the archives, which did not make it into Stallibrass' book, paint a different picture. Some members were indeed picking up on the doctors' theories, permanently monitoring their own achievements through a biological «lens». ${ }^{41}$ A large number of ex-members, however, showed little interest in the research aspect. Many would comment favourably on the affordability of the health check-ups when no health insurance was available to them..$^{42}$ Others recalled the PHC

38 Pearse/Crocker, The Peckham Experiment, 78.

39 A. Stallibrass, Being Me and Also Us. Lessons from the Peckham Experiment, Edinburgh I989.

40 The methodological difficulties in writing the history of charitable medical relationships from «below» have frequently been acknowledged: See, for instance, A. Borsay / P. Shapley (eds.), Medicine, Charity and Mutual Aid. The Consumption of Health and Welfare in Britain, c. 1550-1950, Aldershot 2007.

41 See Reminiscences of St Mary's Road Peckham, I984, WL, SA/PHC/C.20.

42 On the variable importance of economic status in the inter-war British medical services: A. Levene, «Between Less Eligibility and the NHS: The Changing Place of the Poor Law Hospitals in Eng- 
2: Bildunterschrift liefern bitte und Source

Source:

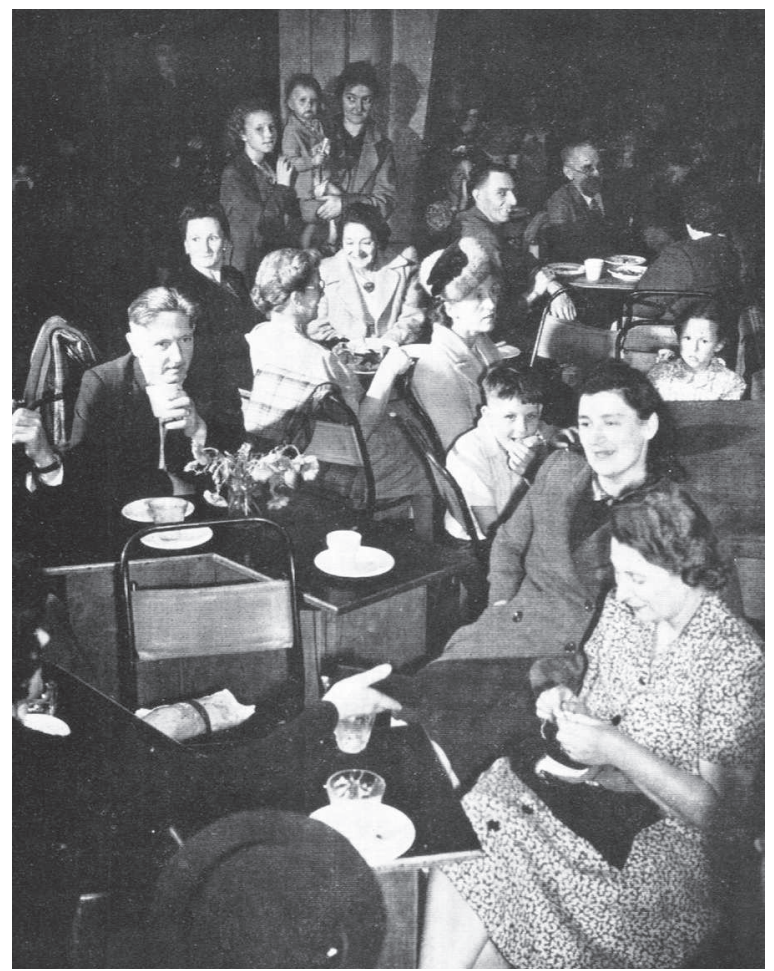

first and foremost as a place were they could enjoy their leisure as parents, since their children were supervised and busy. 43

Even more revealing of the heterogeneity of motives and interpretations on the part of the Centre's members is a periodical that some of them edited in the post-war years. Ironically entitled The Guinea Pig, it communicates a norm of activeness, encouraging improvisation and tolerance of amateurs. ${ }^{44}$ However, The Guinea Pig bears traces of conflicts as well. A recurrent topic is the critique of exclusive cliques in the Centre. Lamenting the lost «Centre spirit» of its early days, the editors would also accuse the postwar members of selfishly using the Centre without considering its research aspect. 45

Finally, photos can serve as additional sources on life in the Centre. One should, however, look very closely at the circumstances in which they were taken. One image in particular, apparently a snapshot of the cafeteria «early on a winter evening», might illustrate that the PHC was far from devoid of power relations, if subtle ones (Figure 2). The image seems to show a relaxed routine in the Centre. All grown-ups are frozen in

land and Wales, I929-39», in: Twentieth Century British History 20 (2009), 322-345.

43 Reminiscences of St Mary's Road Peckham, I984 WL, SA/PHC/C.2O.
44 The Guinea Pig 3, I948, WL, SA/PHC/B.5/I2/I, 3 45 The Guinea Pig I, I948, WL, SA/PHC/B.5/I2/I, 8. 
unconscious movement, hardly taking notice of the photographer. But all the children stare at the camera, betraying the fact that it does capture its own influence on the scene. Apparently, most people in the photo knew very well how to stage informality.

Whatever the reasons for such behaviour on the part of the Centre members, clearly, they reflected upon the objectives of the laboratory they were part of. Scott Williamson and Pearse, however, never commented on how this was affecting the order that, to them, had evolved quite naturally. Additionally, in their writings they never reflected on the extent to which a pre-existing working-class culture of cooperation might have affected the members' behaviour. In general, the two directors were surprisingly unaware of the symbolic capital they held as educated individuals: To many members, the doctors remained representatives of the upper classes, if rather approachable ones. Above all, Pearse and Scott Williamson never discussed to what extent the actions of the Peckham residents had to be seen in light of their poverty, which was moderate, but hardly negligible. Evidently, by the late I930s, the Centre had begun to turn into an echo chamber. The members' actions and the scientist findings were amplifying one another. Consequently, little criticism penetrated the bubble that had evolved around the researchers. Scott Williamson, as Frances Donaldson, one of the original initiators of the Centre, would later note in her memoirs, «could not be moved to any form of compromise with the ideas of other people»..$^{4}$ In fact, his texts were increasingly revealing a strangely cosmological way of thinking.

Eventually, Scott Williamson's inability to thoroughly substantiate his findings contributed to the financial demise of the Centre in 1950. Even before the war, the Centre had been standing on the verge of bankruptcy. In 1939, the directors applied for research grants from the Ministry of Health and the Medical Research Council (MRC). Experts assessed the Centre and pointed to serious flaws in its data. ${ }^{47}$ Scott Williamson had to admit: «[W]e have been groping in the dark for three years and are only now coming out into the light.» ${ }^{48}$ This, however, did not keep him from criticising plans for a nation-wide health system put forward in a 1944 government White Paper. ${ }^{49}$ Following the great success of «The Peckham Experiment», Scott Williamson was frequently asked for his opinion on the matter, but always declined to accept the premise that health insurance should be compulsory, tax-based and administered by the state..$^{50} \mathrm{In}$ stead, he envisioned a market-driven system, based on local health centres and clinics administered by boards of citizens and physicians. In I945, he published an essay on the topic, «Physician, heal thyself». ${ }^{11}$ It was dismissed as utopian, and published too

46 F. Donaldson, Child of the Twenties, London I959, 163.

47 Edward Mellanby to Bradford Hill, 4.5.I939, The National Archives, Kew (TNA), FD I/299.

48 Scott Williamson to Hill, I6.6.I939, TNA, FD I/ 299.

49 A National Health Service. Presented by the Minister of Health and the Secretary of State for Scotland to
Parliament by Command of His Majesty, London I944.

50 «What Experts are Saying about the Health Plan», News Chronicle, I8.2.I944.

51 G. Scott Williamson, Physician, heal thyself: A Study of Needs and Means, London 1945. He had first proposed his ideas in the mid-I930s in the thinktank Political and Economic Planning (PEP). See 
late to have any impact on the structure of the National Health Service (NHS) created three years later.

Meanwhile, in 1946 , the PHC was reopened. To a large extent, this was actually the work of the ex-members. Several hundreds of them had petitioned the Prime Minister to release the Centre from military administration (during the war, the building had been used by a company building radio equipment for the Royal Air Force). Although this display of responsibility on the part of their «guinea pigs» must have prided the directors, they were hesitant to join forces. In fact, Pearse and Scott Williamsons were by now increasingly using the PHC for the purposes of promoting their theories rather than for substantiating them. Both directors went on extensive lecture tours in Britain, the Middle East and the USA, culminating in Scott Williamson address to the General Assembly of the United Nations at Lake Success in March $1948 . .^{52}$ However, the great media coverage the Centre now received did not encourage more donations. Neither did a documentary-film about the Centre made by the Foreign Office in I947. Criticism of the experiment's shortcomings, however, grew louder. A review of «The Peckham Experiment» in Nature argued that «preconceived ideas about «the living structure of society stand in the way of the experimenters», concluding «a biologist is driven to judge the social and the scientific aspects of [their] work very differently.» ${ }^{53}$ Fatally, even a former member of staff claimed: «Many investigators came to [...] Centre and asked where the discipline was, and they always received the answer that there was no discipline. If by this was meant that there were no principles by which people could understand what the limits of their freedom were, this statement is true. But members had only to try something that was disapproved of to find that definite limits were in fact set to social activity. [...] [T]he arbitrariness with which on occasion the staff interfered with the activities of the members was startling.» ${ }^{54}$

Other critics pointed out that an experiment whose objects attribute meaning to the laboratory setting can hardly claim to commit to the standards of controlled and repeatable scientific procedures..$^{55}$ In this regard, some of Scott Williamson's statements were indeed paradoxical: «I was the only person with authority», he claimed in 1946 , «and I used it to stop anyone exerting any authority.» ${ }^{56}$

Alarmed by the criticism, the Health Trust, which was in charge of the finances of the Centre, began pressuring the directors to adapt a sound statistical method and to use control groups to verify their claims. ${ }^{57}$ In 1949, the Trust commissioned another

Memorandum on the preparation of the Report on the British Health Services, I937, London Schoo of Economics, PEP/WG/15/6, I, 2, and J. Lewis / B. Brookes, «The Peckham Health Centre, «PEP», and the concept of general practice during the I930s and I940S», in: Medical History 27 (1983), I5I-I6I

52 American Itinerary, I947, WL, SA/PHC/A.I/4.

53 M. L. Johnson, «Research in Social Organization.
The Peckham Experiment», in: Nature 153 (1944), 269-270, 269 .

54 M. Chance, Where from Peckham?, in: The Lancet 255 (1950), 726-727, 726

55 See, for instance, J.A. Ryle, «The Peckham Experiment», in: Bulletin of Hygiene, I944, 236.

56 Quoted after Ward, A Laboratory of Anarchy, 60.

57 Donald Wilson to Pat Winsley, 9.9.I949, WL, SA/ PHC/B.5/I5. 
outside evaluation of the Centre, which recommended that the directors continue their research under the auspice of the MRC, financed by the London County Council (LCC). However, in compliance with the NHS' universalist agenda, the LCC demanded that the Centre be opened for residents from other parts of the city. Scott Williamson and Pearse deemed this unacceptable. In March I950, the Centre was shut down, to the disappointment of many members, whose public protests received considerable media attention for a couple of months. ${ }^{58}$ The building was sold and reopened as a LCC-polyclinic in I952. Pearse and Scott Williamson had by now begun to blame the closure on hostility towards family life - again, rather unfairly, given the widespread concern with «problem families» at the time ${ }^{59}$ - and towards individual freedom on the part of the proponents of the centralist state. ${ }^{60}$ Rightly, they were pointing out that there was little room for enterprises such as the PHC within the legal framework of the NHS. However, they failed to mention that the families the Centre was serving clearly could not shoulder its running costs. The PHC had always remained one of the philanthropic institutions its founders had originally intended to prove unnecessary.

\section{Conclusion}

In light of the egalitarian ideas about economic redistribution and political citizenship put forward during and shortly after the war, it was easy to dismiss the «Peckham method» as «working in a capitalist state and being very careful not to notice it», as the Socialist Medical Association Bulletin noted in $1947 .{ }^{61}$ However, taking aside this blind spot, as well as the observation that the PHC way was by no means as «pioneering» as its supporters would have it, the amount of freedom the Peckham members enjoyed in the late I930s was rather exceptional. So was the fact that, at least in print, Pearse and Scott Williamson were completely abandoning the idea of ordering human behaviour along normative lines. This points to three implications of this case study.

I. For one, the Peckham experiment holds a peculiar but nevertheless illuminating place in the history of the applied social and natural sciences. In a modernist building in South London, established concepts of social work were fused with environmentalist theories on cooperative evolution, which were further adapted to the specific social interplay in the emerging «laboratory». Within a few years, this resulted in a hands-off approach on the part of upper-middle class professionals towards the problem of social reform. Thus, in terms of historical method, the case of «Peckham» shows that we

58 PHC Members Association: approaches to Parliament and LCC, WL, SA/PHC/B.6/4.

59 See P. Starkey, «The Medical Officer of Health, the Social Worker, and the Problem Family, I943 to I968: The Case of Family Service Units», in: Social History of Medicine, II (I998), 42I-44I.

60 See The Passing of Peckham, I95I, WL, SA/ PHC/B.6/I3.
61 D. Stark Murray, «Doctors into Biologists», in: Socialist Medical Association Bulletin, September I947. On the SMA see J. Stewart, «The Battle for Health». A Political History of the Socialist Medical Association, 1930-51, Aldershot 1999. 
should pay more attention to contingent, micro-historical processes when analysing what Lutz Raphael has termed the «scientification of the social» in the twentieth century. ${ }^{62}$ Much like recent laboratory-anthropology has demonstrated with regards to the hard sciences ${ }^{63}$ historians need to look more closely at confined localities, at «experimental spaces». These spaces have shaped the scientific knowledge on which expert attempts at social planning or «social engineering» were based. In doing so, it is imperative not to take the experts' reports at face value, but to consider the agency and resistances of the people who were being «engineered». ${ }^{64}$ But we also need to take into account that the concepts underlying socio-technical interventionism were in some cases adapted by the very people the experts were concerned with. In the Peckham Experiment at least, appropriations of expert knowledge induced productive repercussions within the very social space in which it was put into practice.

2. This points to a second aspect, which concerns what one might see as a broader trend towards the «experimentalization of the social» in the mid-twentieth century. Pearse and Scott Williamson, somewhat tragically, failed to recognize that the PHC bore much resemblance to, and possibly even influenced other social experiments. I will mention only one of these projects, the so-called «Northfield experiments», ${ }^{65}$ even though interest by experimental sociologists in «Peckham» can be traced as far as to Jakob Moreno's American school of sociometry. ${ }^{66}$ During the war, in the Northfield Clinic near Birmingham, traumatised soldiers were encouraged to self-organise, to form clubs according to their interests, and to discuss their psychosocial difficulties in daily meetings. The military psychologists in the clinic abstained from intervention. Soon, to their own surprise, they observed how the initial anomic situation was turning into a highly effective «therapeutic community». ${ }^{67}$ Importantly, in I946, the Northfield psychologists founded the Tavistock Institute for Human Relations, which would become

62 Summing up recent research: L. Raphael, «Em bedding the Human and Social Sciences in Western Societies, I880-I980», in: K. Brückweh et al. (eds.), Engineering Society. The Role of the Human and Social Sciences in Modern Societies 1880-1980, Basingstoke, London 20I2, 4I-58.

63 Two now-classic studies are B. Latour, Science in Action. How to Follow Scientists and Engineers through Society, Milton Keynes I987; and H. J. Rheinberger, Experimentalsysteme und epistemische Dinge. Eine Geschichte der Proteinsynthese im Reagenzglas, Göttingen 200I.

64 Most of the older research on social engineering focuses on its inherent inhumanity. See, for instance, Z. Baumann, Modernity and Ambivalence, Ithaca, N.Y I99I; and J.C. Scott, Seeing Like a State: How Certain Schemes to Improve the Human Condition Have Failed, New Haven I998. For a more recent case study on the ambivalences of social engineering see T. Etzemüller, Alva and Gunnar
Myrdal. Social Engineering in the Modern World, Lanham/MD 20I4. For a conceptual approach: T. Etzemüller, «Social Engineering als Verhaltenslehre des kühlen Kopfes. Eine einleitende Skizze», in: Idem (ed.), Die Ordnung der Moderne. Social Engineering im 20. Jahrhundert, Bielefeld 2009, II-39.

65 T. Harrison, Bion, Rickman, Foulkes and the Northfield Experiments. Advancing on a Different Front, London 2000.

66 M. Rogers, «The Peckham Experiment», in: Sociometry 8 (I945), 92-96. See reference 3 and 4 regarding the PHC's legacy beyond the social sciences.

67 H. Bridger, «The Discovery of the Therapeutic Community. The Northfield Experiments», in: E. Trist, Eric / H. Murray (eds.), The Social Engagement of Social Science. (SESS) A Tavistock Anthology, 1: The Socio-psychological perspective, Philadelphia I990, 68-87, 76 . 
pivotal in popularising knowledge about the therapeutic and economic potential of the spontaneous self-management of social groups, influencing both political elites and corporative executives. Based on their experiences in experimenting with «leaderless groups», in the post-war decades, the Tavistock scientists began to look upon authority as an obstacle to productivity, political participation and self-fulfilment. The point to be made here is that the Peckham experiment primarily attracted so much attention throughout the second half of the twentieth century because it was being associated with insights triggered by later research. ${ }^{68}$ But the Tavistock scientists actually went much further than Pearse and Scott Williamson (for whom the biological family unit always remained at the core of their experiment) in considering self-organisation and individual flexibility as resources rather than problems. In the ig6os, feedback in experimental, open situations was increasingly regarded as an ideal technique for developing subjects that were freethinking and adaptive to change.

3. Recent scholarly criticism tends to regard these new forms of group experimentation as crucial in the establishment of norms which are widespread today: ${ }^{69}$ Increasingly, the individual's ability to motivate itself, rather than the societal position it holds, is seen as the key to success in life. Social theorists like Nikolas Rose (who has worked extensively on the Tavistock programme) point out that we are therefore pressured to permanently explore and evaluate the self-as-project in response to shifting economical contexts. ${ }^{70}$ In maintaining this pressure - especially on the less privileged parts of the population - governments often rely on intermediary, privately run institutions. These institutions do in fact remotely resemble the PHC in that they channel this pressure locally, by «governing through community», by inclusion rather than control..$^{71}$ It is thus tempting to regard «Peckham», as an avant la lettre training ground for a contemporary type of governmentality ${ }^{72}$ - especially in light of its recent reappraisal by selfproclaimed «social entrepreneurs» like Andrew Mawson.

However, looking at its records, and considering, for instance, the naturalisation of gender-specific types of activity in the Centre, it is easy to put it in historical perspective. Moreover, any attempt at painting the PHC as a quasi-postmodern phenomenon is simplistic: It builds on a stark contrast between high modernist top-down planning and more liberal types of governance, a contrast which itself is a historical chimera: Since the late I980s, it has frequently been suggested that the British post-war state

68 Colin Ward readily associated «Peckham» with the «leaderless group»: Ward, Anarchism as a Theory of Organization.

69 See, for instance, E. Horn, «Test und Theater. Zur Anthropologie der Eignung im 20. Jahrhundert», in: U. Bröckling / E. Horn (eds.), Anthropologie der Arbeit, Tübingen 2002, I09-I25.

70 N. Rose, Governing the Soul. The Shaping of the Private Self, London I990. Similar arguments are put forward by L. Boltanski / É. Chiapello, The New
Spirit of Capitalism, London, New York, 2005; and U. Bröckling, Das unternehmerische Selbst. Soziologie einer Subjektivierungsform, Frankfurt a. M. 2007.

71 N. Rose, Powers of Freedom. Reframing Political Thought, Cambridge I999, 86-89.

72 See R. Kozlovsky, The Architectures of Childhood. Children, Modern Architecture and Reconstruction in Postwar England, Farnham 2013, who draws heavily on Rose's observations. 
crowded out established forms of mutual aid and voluntary action, thus crushing civil society, weakening social bonds and diminishing social responsibility or - as recent political rhetoric had it - destroying the «Big Society». ${ }^{73}$ In truth, many voluntary organisations were driving the state into practices of provision in the I930s and I940s, and even influential proponents of the welfare state were envisioning complementary roles for private initiatives and public administration. ${ }^{74}$

All three points considered the Peckham experiment demonstrates that, as historians, we are well advised to remain receptive to the many nuances of science-based regimes of activation. A micro-historical perspective, which brings to light the contingencies and contradictions that shape the knowledge-basis of such regimes, can keep us from falling for unhistorical generalizations.

A Laboratory of Anarchy? The London Pioneer Health Centre and the Experimentalization of the Social, I935-1950

This article takes a micro-historical look at the «Peckham Experiment», conducted in South London between I935 and I950. In the «Pioneer Health Centre», workingclass families could freely organize recreational activities, their physical and social development being closely observed by physicians. The article traces how theories on social evolution were structuring the doctors' gaze on an experimental space originally conceived to study the effects of health promotion. It also argues that the scientists' hands-off attitude evolved out of epistemological challenges they were facing when interacting with their «guinea pigs». In a bestselling I943 book, the experimenters were rejecting interventionist thinking, theorizing on the creative potential of individuals and the power of social groups to self-organize - generating insights that were discussed around the world, still haunting British political debates today. The article thus serves as a case study on hopes placed in social experimentation in the 2oth century and its «gouvernmental» effects.

73 P. Thane, «The «Big Society» and the «Big State»: Creative Tension or Crowding Out?», in: Twentieth Century British History 23 (2012), 408-429.

74 See G. Finlayson, Citizen, State and Social Welfare in Britain, Oxford 1994. With a short mention of the PHC: A. Beach, «Forging a «nation of participants»: Political and Economic Planning in Labour's Britain», in: idem./ R. Weight (eds.,) The Right to Belong. Citizenship and National Identity in Britain, I930-I960, London I998, 98-II5. 
ABSTRACT

\section{ABSTRACT}

David Kuchenbuch

Justus-Liebig-Universität Gießen

Historisches Institut, Neuere Geschichte I

Otto-Behaghel-Str. 10

D-35394 Gießen

e-mail: David.Kuchenbuch@geschichte.uni-giessen.de 
Anette Schlimm Planning Order and Self-Organisation.
The Regulation of Competition
and Spatial Relations in
Inter-War Transport Expertise

Planning history of the first half of the twentieth century has long been focused on large-scale projects. Due to research on a great variety of projects such as the Tennessee Valley Authority or utopian «white elephants» like the Atlantropa project of the German engineer Hermann Sörgel, the «Generalplan Ost» or the efforts of inner colonisation in Europe, our understanding of the alliances between engineering, scientific experts and politic power has grown considerably. ${ }^{1}$

James C. Scott has described those planning processes as based on a high modernist ideology, which was widely spread among «planners, engineers, architects, scientists, and technicians», and characterised as the will (and the confidence of being capable) to organise and regulate not only technological aspects of the modern world, but also natural, social and (most generally) human aspects of the world in general. ${ }^{2}$ This ideology resembles in many respects the ideology of technocracy, which formed a small but famous movement in the United States as well as in Germany. ${ }^{3}$ But while the technocracy movement as such was limited to a relatively small number of members, its

1 For TVA see, for example, D. Ekbladh, «Meeting the Challenge from Totalitarianism: The Tennessee Valley Authority as a Global Model for Liberal Development, I933-I945", in: The International History Review 32 (2010), 47-67. For Atlantropa and «white elephants», see A. Gall, Das AtlantropaProjekt - die Geschichte einer gescheiterten Vision. Hermann Sörgel und die Absenkung des Mittelmeers, Frankfurt a. M., New York I998; D. van Laak, Weiße Elefanten. Anspruch und Scheitern technischer Großprojekte im 20. Jahrhundert, Stuttgart I999, I66-I73. For GPO see, among others, I. Heinemann, «Rasse, Siedlung, deutsches Blut». Das Rasseund Siedlungshauptamt der SS und die rassenpolitische Neuordnung Europas, Göttingen 2003 M. Rössler / S. Schleiermacher (eds.), Der «Generalplan Ost». Hauptlinien der nationalsozialistischen Planungs- und Vernichtungspolitik, Berlin I993.
And for «inner colonisation», see L. van de Grift, «On New Land a New Society: Internal Colonisation in the Netherlands, I9I8-I940», in: Contemporary European History 22 (2013), 609-626; M. Weipert, «Mehrung der Volkskraft». Die Debatte über Bevölkerung, Modernisierung und Nation 18901933, Paderborn et al. 2006, 8I-88.

2 J. C. Scott, Seeing Like a State. How Certain Schemes to Improve the Human Condition Have Failed, New Haven, CT I998, 5 .

3 Ch. S. Maier, «Zwischen Taylorismus und Technokratie. Gesellschaftspolitik im Zeichen industrieller Rationalität in den zwanziger Jahren in Europa», in: M. Stürmer (ed.), Die Weimarer Republik. Belagerte Civitas, Königstein I980, I88-213; S. Willeke, Die Technokratiebewegung in Nordamerika und Deutschland zwischen den Weltkriegen. Eine vergleichende Analyse, Frankfurt a. M. I995. 
fundamental ideas became more and more influential. In order to emphasise the widespread influence of these ideas, Dirk van Laak has described them as a «background ideology» among scientists and engineers, administrative elites and also some politicians. ${ }^{4}$

The focus on large-scale projects as well as the ideology of high modernism implies that the first half of the twentieth century was first and foremost the high tide of topdown planning and authoritarian interventions - a conclusion that is undoubtedly correct, in particular with regard to authoritarian political systems like National Socialist Germany. It is, additionally, often associated with the perception that these planning processes were directed towards a specific spatial concept: the strict separation of different spaces which were to be internally centralised and homogenised. This form of spatial interventionism is often discussed in relation to the «territoriality» that has been described by Charles Maier as a characteristic of the era between I860 and I970. In his classical essay from 2000, Maier identified a global coherence of the era in which the territory itself became an instrument of power. In this period, two aspects of the territory became particularly crucial: the borders and the space within. The political practices of drawing up and strengthening frontiers are unquestioned in their importance for the history of the nineteenth and twentieth century, the era of nation states. Maier, however, puts an emphasis also on the relevance of processes that concern the exploitation of the land within. By means of describing the era of territoriality not only as a period of strict border regimes, but also as one of centralisation processes, he is capable to shed light onto how old, more decentralised forms of power perished and new techniques of maintaining power within the territory appeared and evolved; transport facilities and new forms of governance and administration became more important and were a stabilising factor for the centralised (nation) state. ${ }^{5}$ Maier's considerations on the age of territoriality as well as the coinciding reflections about a «spatial turn» in history have inspired many scholars to explore the territorial character of modern states and the relations of power and to analyse border regimes, the construction of (national) spaces by cartographic practices as well as the spatial expansions in imperial and colonial contexts. ${ }^{6}$ A noteworthy field of interest in the last years has been that of «exceptional spaces». These «exceptional spaces» are territories that were perceived as

4 D. van Laak, «Jenseits von Knappheit und Gefälle. Technokratische Leitbilder gesellschaftlicher Ordnung», in: H. Berghoff / J. Vogel (eds.), Wirtschaftsgeschichte als Kulturgeschichte. Dimensionen eines Perspektivenwechsels, Frankfurt a. M. 2004, 435-454.

5 Ch. S. Maier, «Consigning the Twentieth Century to History: Alternative Narratives for the Modern Era», in: The American Historical Review I05 (2000), 807-831, 8I7, 8I8-82I.

6 See J. Döring / T. Thielmann (eds.), Spatial turn.
Das Raumparadigma in den Sozialwissenschaften, Bielefeld 2008. See, among others, C. Dipper / U. Schneider (eds.), Kartenwelten. Der Raum und seine Repräsentation in der Neuzeit, Darmstadt 2006; U. Jureit, Das Ordnen von Räumen. Territorium und Lebensraum im 19. und 20. Jahrhundert, Hamburg 20I2; I. Schröder / S. Höhler (eds.), Welt-Räume. Geschichte, Geographie und Globalisierung seit 1900, Frankfurt a. M. 2005; D. van Laak, Imperiale Infrastruktur. Deutsche Planungen für die Erschließung Afrikas 1880-1960, Paderborn 2004. 
«empty» or «exploitable», and in which brutal acts of violence took place, such as colonial spaces and peripheries of empires as described by Timothy Snyder. ${ }^{7}$ Yet concurrent practices of constructing and exploiting space other than the aforementioned are often disregarded.

This exclusive focus on radical and extraordinary projects ignores, however, the many every-day and moderate planning processes in the first half of the twentieth century, which were not only based on a more complex idea of structured and hierarchical spaces, but also on a specific combination of top-down planning and (small) spaces of self-organisation. Governments as well as regional and local authorities enforced a new internal structure of space during the era of territoriality. These planning processes influenced most aspects of the every-day life of many people and had strong long-term effects. In this contribution, I will focus on these «normal» planning processes, particularly with a view to analysing transport planning. In so doing, I will concentrate on two interrelated problems:

Firstly, I will analyse what types of top-down or bottom-up planning and organisation were put into action in order to realise a rational and smooth transport - and social - order. Secondly, I will scrutinise the spatial concepts these planning processes were based on. Thereby, I will ask for the less well-known forms of ordering space behind radical and large-scale projects. Thereby, another type of high modernist planning practice becomes visible: small-scale and more flexible, but by no means a democratic or even congenial form of ordering the social.

The objects of my analysis will be the German and British transport experts. These two national cases seem suitable for the aim of analysing the rather every-day-practices of transport expertise, especially concerning the inter-war years. When the different transport systems which had emerged during the nineteenth century began to converge after the First World War, transport experts in both countries had to cope with the same problem: the growing competition between railways and road transport. ${ }^{8}$ Even though the institutionalisation of transport expertise and the political and social contexts differed fundamentally in both countries, no radical different spatial practices took place. Therefore, my argument will not lead into a straight national comparison. Instead, I intend to outline a transnationally existing form of planning which can help to broaden the perspective on planning history in high modernity.

7 T. Snyder, Bloodlands. Europa zwischen Hitler und Stalin, München 20II; see also J. Baberowski / A. Doering-Manteuffel, Ordnung durch Terror. Gewaltexzesse und Vernichtung im nationalsozialis tischen und im stalinistischen Imperium, Bonn 2006.
8 For a European survey of transport policy see R. Filarski / G. Mom, Shaping Transport Policy. Two Centuries of Struggle between the Public and the Private Sector. A Comparative Perspective, Den Haag 2 OII. 


\section{Transport Studies in the Inter-War Years - Development and Stabilisation}

The tendency to critically examine transport processes began in both countries during the nineteenth century, coinciding with the expansion of the railway network. Authors like Friedrich List stressed the politically unifying forces of the railways, which had to be completed by a political union in Germany. ${ }^{9}$ Yet the principal problem was the legal and economical alternative of public or private ownership of railways and canals. During the nineteenth century, the idea of publicly owned infrastructure was increasingly supported, in particular in Germany. Conversely, privately owned railway companies were only legally regulated in Great Britain - mostly with respect to security, accountability and accessibility. ${ }^{10}$

While these questions were initially mainly discussed by economists, jurists and politicians, and especially with regard to the railways, the institutionalisation of transport studies as a distinct field of knowledge took only place after the First World War. One factor for this development might have been the experience of a stricter administration of the transport sector during the war. In the immediate aftermath of the war, it seemed thus equally necessary to develop civil forms of a general transport administration, especially because of the growing number of lorries formerly owned by the armed forces. The setting up of governmental transport departments like the Ministry of Transport in Great Britain and the Reichsverkehrsministerium in Germany were related to an even wider awareness of the importance of transport problems, which later also led to the foundation of specialised transport newspapers as well as institutions in which the emerging group of transport experts organised themselves.

Nonetheless, the specific forms of expertise were quite different. German transport experts were mainly found in newly founded departments for transport studies. In contrast, British experts met at the Institute of Transport, a learned society. These transport experts were primarily practitioners and often worked for transport companies in the administration and management sector. ${ }^{11}$ Despite the obvious differences between these institutional forms of expertise, both communities of experts shared some distinct features. Both experts' cultures can be characterised by a strict habitus of rationality as well as social responsibility: in both countries, the transport specialists believed to serve the common interest with their specialised knowledge.

After the First World War and the first period of institutionalisation, a longer period of difficulties for the new field of expertise began. In Great Britain, the short era of re-

9 A.-F. Napp-Zinn, Friedrich List als Verkehrspolitiker, Mainz I948; R. Roth, «Die Bedeutung des transatlantischen Diskurses für das deutsche Eisenbahnnetz und die Rolle Friedrich Lists», in: D. Dahlmann / R. Reith, Elitenwanderung und Wissenstransfer im 19. und 20. Jahrhundert, Essen 2008 , I5-34.
10 H. J. Dyos / D. H. Aldcroft, British Transport. An Economic Survey from the Seventeenth century to the Twentieth, Leicester I97I, II7-I86.

11 See A. Schlimm, Ordnungen des Verkehrs. Arbeit an der Moderne - deutsche und britische Verkehrsexpertise im 20. Jahrhundert, Bielefeld 20II, 75-III. 
construction ended at the beginning of the I920s, and the re-organisation of the transport sector became less important for the governmental and the public interest. ${ }^{12}$ The scientific experts in Germany at the University of Cologne, for example, were faced with major financial difficulties. During the I920s, the experts in both countries sought to stabilise their institutions and to build an audience for their expertise - in transport companies, in public administration and in the political sphere. According to the different political cultures, administrative traditions and styles of expertise, these addressees differed considerably, and so did consequently the planning styles and degrees of intervention. ${ }^{13}$ After the great reforms of railway companies in the early I920s, the scale of transport planning was reduced to a regional or local level until the late I920s. Subsequently, the growing competition between railways and lorries coincided with the Great Depression, and in this situation state interventionism and large-scale planning in the transport sector became acceptable again.

These regulative ideas were based on a specific diagnosis of crisis in the transport sector. Many experts perceived an exacerbating social and spatial disorder, for example a growing disequilibrium between rural and urban regions caused by accelerated modernisation processes. Even in rather organisational contexts, this perception of crisis and disorder caused by modernity was the basis of a specific form of interventionism. The organisational task of creating new authorities of transport administration for larger agglomerations like the Ruhr area or Greater London were related to the wider contexts of creating a new order of settlement, spatial decentralisation or prevention of augmenting migration. ${ }^{14}$ By these attempts to build up a new transport order, experts believed that also problems of industrialisation, urbanisation, in brief: modernity could be solved. ${ }^{15}$

12 H. P. Maybury, «Presidential Address», in: The Journal of the Institute of Transport 3 (IO2I) I, I5-22; K. Hey, «Transport Co-ordination and Professionalism in Britain. Forging a New orthodoxy in the Early Inter-war Years», in: The Journal of Transport History 3I (20IO), 25-4I.

13 For the different conjunctures of interventionism in the transport sector see A. Schlimm, «Verkehrseinheit und ruinöser Wettbewerb. Der «SchieneStraße-Konflikt in Großbritannien und Deutschland als ein Problem des Social engineering», in: Geschichte und Gesellschaft 39 (2013), 338-368; for the longue durée of transport regulation see D. Klenke, Bundesdeutsche Verkehrspolitik und Motorisierung. Konfliktträchtige Weichenstellungen in den Jahren des Wiederaufstiegs, Stuttgart I993.

14 See K. Pirath, «Die Entwickelungsrichtung des Verkehrs im rheinisch-westfälischen Industriege- biet und die Schnellbahnpläne», in: Verkehrstech nische Woche. Zeitschrift für das gesamte Verkehrswesen 22 (I928), 405-409, 42I-424, 434-438; B. Walter, «Das Scheitern der Rheinisch-Westfälischen Schnellbahn in den I92oer Jahren - Regionale Verkehrsentwicklung, technische Innovation und Interessenpolitik», in: W. Reininghaus / K. Teppe (eds.), Verkehr und Region im 19. und 20. Jahrhundert. Westfälische Beispiele, Paderborn I999, 20I-248.

15 J. W. Korte, «Der Verkehr in der Stadtplanung», in L. Brandt (ed.), Stadtverkehr heute und morgen, Düsseldorf I954, I2-44; K. Leibbrand, «Die Verkehrsnot der Städte», in: C.-G. Bennholdt-Thomsen (ed.), Der Mensch in der Großstadt. Eine Vortragsreihe, Stuttgart I960, I03-II5. 


\section{Cornish Milk Logistics - An Unremarkable Example of Transport Planning?}

Literary historians have used anecdotes - short, not necessarily canonical texts or fragments - to make relationships visible which are otherwise hard to uncover. This approach can be helpful here, too. ${ }^{16}$ By analysing and contextualising an unremarkable transport plan as an anecdote, I will show how even this inconspicuous intervention reveals many characteristics of inter-war transport discourses, and these are the characteristics that will shed new light on the every-day planning practices and implementations in inter-war Europe in a rather different form than radical and large-scale variants.

In 1933 , the Railway Gazette, a British weekly newspaper for railway professionals, published a rather extensive and richly illustrated article. ${ }^{17}$ Entitled «Co-ordinated Transport of Cornish Milk», the article informed the readers about a new milk collecting system, which had recently been established by the Great Western Railway and Nestle in Cornwall. The piece explained how the collection of more than 7000 gallons of fresh milk from over 600 farms throughout Cornwall was organised on a daily basis in order to transport milk to the central collecting point at Lostwithiel station. Light lorries collected the milk at each farm and brought it to Lostwithiel where a train departed to Nestle for final processing, bottling and distribution to the consumer.

This new scheme was presented as rational and smooth. For the perfect flow of milk and its transport, Cornwall was subdivided into 24 sectors. Ten sub-centres were established to which the lorries delivered the collected milk before it was finally transported to Lostwithiel. This hierarchical system of grouped sectors and centres on different levels formed a new spatial order of Cornwall. It did not follow any existing patterns, such as the system of administrative regions; instead, it was directly shaped by the requirements set by the milk collecting traffic (Figure I). Additionally, it covered the whole territory without any overlapping.

The planning process was a great challenge for the railway company and its expert Fulwar C. A. Coventry, the superintendent of Road Transport. It included meticulously collecting necessary information (e. g. address lists of milk-producing farms), personally inspecting the whole region as well as calculating time-tables for lorries. The most important part of the planning process remained, however, the task of locating the lorry centres and traversing the 24 different milk-collecting routes, which had to be allocated to the sub-centres. The combination of new, dispersed and extensive traffic was the major challenge for the planning process, yet it was a great success according to the Railway Gazette: «Subject to minor difficulties inseparable from a completely new

16 S. Greenblatt, «Erich Auerbach und der New Historicism. Bemerkungen zur Funktion der Anekdote in der Literaturgeschichtsschreibung», in: idem, Was ist Literaturgeschichte?, Frankfurt a. M. 2000, 73-100.
17 Anonymous, «Co-ordinated Transport of Cornish Milk», in: The Railway Gazette 58 (I933) Io, 332335 . 


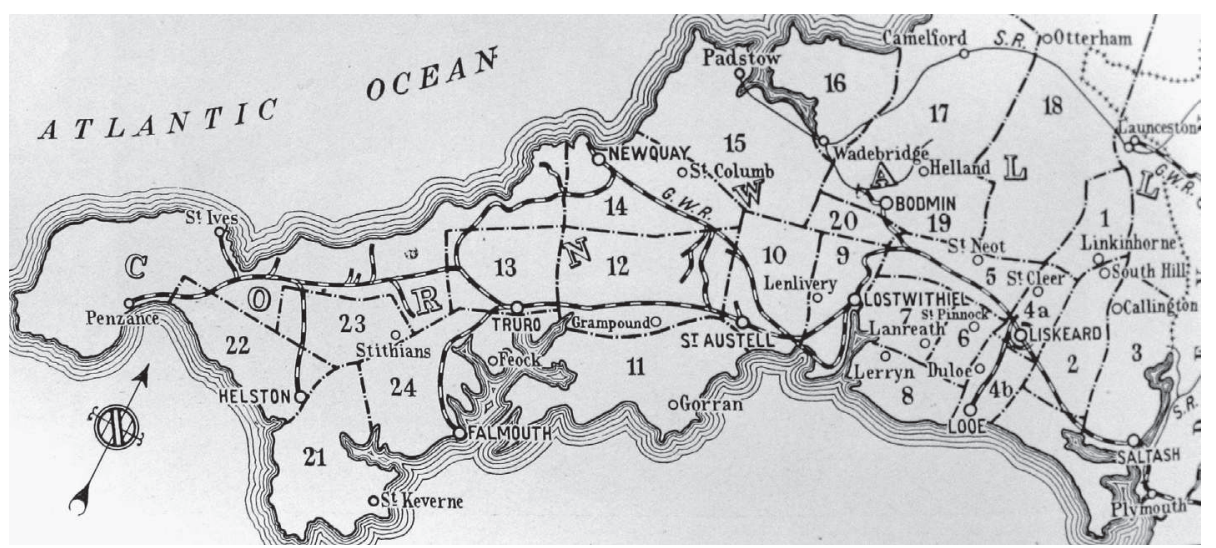

1: The Cornish Milk Transport System

Source: Anonymous, "Co-ordinated Transport of Cornish Milk», in: The Railway Gazette 58 (1933) 10, 332-335, 332.

transport system of this magnitude, the scheme soon began to function smoothly and efficiently.» ${ }^{18}$

At first glance, the article seems to deal solely with rational planning in an industrial society, where both, production and distribution of groceries, followed the rationale of logistics and industry. Yet the most interesting part of the article in the Railway Gazette is still to be told. According to the newspaper, the artificial spatial regime proved to be able to establish a new form of organisation, namely the self-organisation and co-operation of transport facilities bottom-up. Immediately after the implementation of this new scheme, first modifications emerged - self-organised, without planning or even permission by the Great Western Railway. The drivers began to use the trains of the Great Western and established a hierarchy of light and heavy lorries. The light vehicles no longer went the whole way to their sub-centre, but only to new, informal collecting and meeting points where the milk was transferred to heavier lorries. While the light ones were able to make a second round to collect more and fresher milk from the farms, the heavier vehicles delivered the milk to a local station where it was transferred to a train, sometimes even a passenger train, heading to Lostwithiel. The spatial system established by the transport expert continued to be used, but the transport flow was now able to bring itself to perfection, self-regulated and self-ordered. The Railway Gazette was very impressed by this development.

The article, published in a specialists' newspaper, might be seen as a negligible episode in the history of logistics. However, its publication in an experts' journal suggests that the article was intended to present a successful example of how the challenge to form a thorough and extensive organisational pattern for a specific sector was coped 
with perfectly. These discursive elements become visible also in other texts by transport experts as well as in political attempts to regulate the transport sector during the interwar years. The anecdote, to follow Stephen Greenblatt, becomes (by thorough analysis) representative for its time and specific context - not by strict parallelising, but by underlining the resonance of the anecdote in other texts. ${ }^{19}$ Thus, this strongly condensed singularity about milk logistics in Cornwall reveals the strong conjunction of spatial order and planning, the relation between top-down and bottom-up organisation, of hierarchy and co-operation in transport.

\section{The Unity of Transport}

The article in the Railway Gazette features some major characteristics of the professional transport discourse between the wars. One can identify in this piece, for example, the prominent position of the expert and of the underlying values of empirical knowledge and efficiency for all planning tasks. In the following, I will concentrate on three further characteristics that are displayed in the article: the importance of the unity of transport, the hierarchical spatial structure and the margins for self-organisation.

One important aspect of the anecdote is the practiced co-operation of different transport facilities. There is no apparent emphasis on this fact; it rather seemed to be natural that the co-operation of lorries and railways was necessary and desirable to exploit a certain territory. All available transport facilities together were to solve the complex task of milk collecting traffic in Cornwall: trains (both freight and passenger trains) as well as lorries (light and heavy ones). This is a typical feature of the transport discourse in the inter-war years. The creation of a smooth transport system, overwhelming all existing forms of traffic and communications, was the greatest challenge for the new field of knowledge.

Transport studies, as outlined by transport experts, covered all forms of transport facilities - railways, air transport, road transport, etc. - as well as transport relations (local and long-distance traffic) and economic forms (public sector and private enterprises). ${ }^{20}$ This required a new definition of transport which would embrace all physical and non-physical, local and mobile, economic, political, and social aspects of traffic and mobility in one concept. As a consequence, transport became described as a social function, constitutive for all sectors of society: social, political, economic and cultural. The German transport expert Carl Pirath suggested an abstract definition of transport in which transport was to assist the three basic functions of social life («Volk», «nation» and «national economy» ${ }^{21}$ ), whereas the initiator of the British Institute of Transport found a rather catchy picture to outline the invisible and organic nature of transport:

19 Greenblatt, «Erich Auerbach», 79, 87, 98.

20 See A. F. Napp-Zinn, «Grundbegriffe des Verkehrs», in: Zeitschrift für Verkehrswissenschaft I8 (I943), 4, 2OI-233.
21 C. Pirath, Die Grundlagen der Verkehrswirtschaft, Berlin I949 (2nd ext. ed.), I. 
Whenever the word Traffic is used, the picture that commonly presents itself to the mind is one of railways and roadways, docks and harbours, canals and inland waterways. I venture to suggest that that is not an altogether adequate mental concept of the term. Traffic as I understand it, is no more locomotives and trains, tramways and omnibuses horsed and power driven vehicles than say cricket is a bat, a ball and a pair of stumps. True, they are the implements of the game; but the game itself, that is the teamwork of a number of men, striving under definite rules and regulations for a common end, utilising the instruments on definite well ascertained principles, designed to achieve the maximum result with a minimum effort. $^{22}$

Thus, in both expert cultures, the concept of interdependence of all forms of transport was a crucial feature. German scientific experts sought to develop abstract definitions and ensured the coherence of the transport sector with a view to its fundamental social tasks, while in many British statements the coherence of an industrial sector seems to have been of greater importance. But nonetheless, the social charging of transport can equally be found in British contexts. ${ }^{23}$

Both groups of experts favoured interventions in order to ensure that the collaboration between the still competing branches of the industry could be realised. The main field of discussion for transport experts and also the main challenge for transport policy in the interwar period, even until the early I960s, was competition in the transport sector, which was perceived as problematic (at best) or even dangerous (at worst). ${ }^{24}$ While this had been quite a subordinated topic around the fin de siècle, when infrastructure provision in a worldwide context was of major importance, ${ }^{25}$ it quickly became a major topic in transport expertise after the First World War - brought about and accompanied by the massive establishment of motorised street transport and the growing importance of efficiency in a situation that was characterised by constant economic problems. ${ }^{26}$ The relation between railways and inland water navigation was also discussed quite extensively in the first half of the I920s (at least in Germany) until the

22 H. H. Gordon, «Manuscript of the address at the first meeting for the foundation of the Institute of Transport», o8/I9I9. Papers of the late H. H. Gordon relating to the foundation of the Institute of Transport; Archives of the Chartered Institute of Logistics and Transport, Corby/GB.

23 See the debates concerning the foundation of the Ministry of Transport: Anonymous, «Ministry of Ways and Communications Bill. Second Reading Debate in House of Commons. The Orders in Council Clause Withdrawn», in: The Railway Gazette 30 (I9I9) I2, 537-545, esp. 537, where the «driving, vitalising power of transportation power» was described as a contemporary perception. See also D. H. Aldcroft, British Transport since 1914: an Economic History, North Pomfret, VT I975, I829; St. Glaister et.al., Transport Policy in Britain, Basingstoke, New York 2006; P. Headicar, Transport Policy and Planning in Great Britain, London, New York 2009, 66; Hey, «Transport Co-ordination".

24 See R. Filarski / G. Mom, Shaping Transport Policy, II3-I75.

25 See van Laak, Imperiale Infrastruktur, 45-99.

26 Royal Commission on Transport, Final Report. The Co-ordination and Development of Transport, London I93I, 84; R. Vahrenkamp, Die logistische Revolution. Der Aufstieg der Logistik in der Massenkonsumgesellschaft, Frankfurt a. M. 201 II. 
«road-rail problem» became the dominant topic in transport debates during the interwar years. ${ }^{27}$

The main characteristic of the problem was not only the confrontation between old and new transportation technology, but also the difference concerning their economic mode. Railways were subdued to specific political regulations, in particular the system of tariffs ${ }^{28}$ and legal obligations like the «Beförderungs- und Betriebspflicht» of the Deutsche Reichsbahn. ${ }^{29}$ In Germany as in Great Britain, the railways were seen neither as a «normal» economic sector nor as an ordinary field of state policy. During the interwar years, both systems - the Staatsbahn-system in Germany and the privately owned railway companies in Great Britain - were altered considerably. The result were hybrid forms of private and state ownership (in Germany) and of unbound and politically controlled decision making and regulation (in Great Britain). In both contexts, the railways were perceived as facilities which had to serve not only economic purposes, but also the common interest. ${ }^{30}$

On the other hand, the road transport industry in both countries was a highly heterogeneous field of many small and a few bigger enterprises which often operated on a small revenue base. Notably in the crisis-driven economy of the ig2os, «uncontrolled growth»(«Wildwuchs») in the freight companies' sector was discussed frequently. ${ }^{31}$ Smaller companies seemed to cause problems in the transport sector by price-cutting competition to the detriment of the quality of transport, but also to long-term effects of transport. For example, economic health of the enterprise in the medium run, the maintenance of infrastructure like roads and even a (perceived) healthy regional and social order seemed to be challenged by the short-term freight competition furthered by small companies. Therefore, the conflict between railway and road traffic was quickly interpreted as a conflict between common good («Gemeinwohl») and self-interest («Eigenwohl»). ${ }^{32}$ While railways were seen as safeguarding the public interest, road transport enterprises seemed to epitomise egoism, greed and the dark side of capital-

27 See G. Sjöblom, «The Shift from Railways to Roads. Four Propositions about the Interwar Period in Britain and Germany», in: Jahrbuch für Wirtschaftsgeschichte 2007, 55-65.

28 See R. J. Eaton, The Elements of Transport, London I936, 46-47; P. Helfrich, «Am Kreuzweg der Verkehrspolitik: 〈Gemeinwirtschaft〉 oder 〈Marktwirtschaft im Verkehrswesen?», in: Zeitschrift für Verkehrswissenschaft 25 (I954) I, 39-55.

29 After the First World War, the former Ländereisenbahnen (federal railways) were united under the central control of the Reichsverkehrsministerium (national transport ministry). In I924, the Deutsche Reichsbahn became partly independent when it was transformed into a state-owned enterprise («Deutsche Reichsbahn-Gesellschaft»). See M. Pohl / S. Kill, «Von den Staatsbahnen zur Reichsbahn
I9I8-I924", in: L. Gall / M. Pohl (eds.), Die Eisenbahn in Deutschland. Von den Anfängen bis zur Gegenwart, München I999, 7I-I07.

30 E. Kolb, «Die Reichsbahn vom Dawes-Plan bis zum Ende der Weimarer Republik», in: Gall / Pohl (eds.), Eisenbahn in Deutschland, Io9-I63, esp. Io9-I24; A. C. Mierzejewski, The Most Valuable Asset of the Reich. A History of the German National Railway, Vol. I: I920-I932, Chapel Hill, NC I999.

31 See H. Baumann, «Zur Einführung», in: O. Blum / H. Baumann (eds.), Verkehrsmittel untereinander. Ihre Aufgaben im Rahmen einer gesunden Verkehrspolitik, Berlin I93I, 2; Royal Commission on Transport, Final Report, 84 .

32 See E. Salin (ed.), Deutsche Verkehrsprobleme der Gegenwart. Verhandlungen der Friedrich-List-Gesellschaft am 29.10.1927 in Berlin, Berlin I928, I2, 
ism. In Germany, this conflict was immediately interpreted as an existential one, whereas the crisis diagnosis in Great Britain was slightly weaker. Nonetheless, in Great Britain structural changes in the transport sector were equally conceived as a problem; the idea was to pacify the perceived conflict by means of putting the whole transport sector into a new order. In I929, the Royal Commission on Transport was appointed to develop constructive suggestions on how «the problems arising out of the growth of road traffic» could be solved. ${ }^{33}$

In most historiographical contexts, these approaches to establishing a new order in the transport sector are analysed and interpreted only as economic regulations. As a result, the main points of interest are the tariff schemes, the systems of licensing and the interventions in the organisational structure of transport companies, which were politically implemented in the I930s and I940s in Great Britain and Germany. ${ }^{34}$ Considering the Cornish Milk anecdote, however, the problem of competition in the transport sector can also be interpreted with respect to the underlying spatial concepts. In the success story in Cornwall, no competition could be observed between the different facilities. On the contrary, the system was based on the division of labour between railways and lorries. This division of labour was the Holy Grail that both groups of transport experts were looking for: to organise all available means of transport in such a way that there would be no competition and oversupply, no parallel services and no regions without any connection. The Cornwall anecdote can be defined as a small-scale example for an existing ideal transport organisation: a «Verkehrseinheit» or a «co-ordinated transport system».35

\section{The Structure of Space}

The co-ordinated transport system, as it was presented in the Cornwall example and as it was sought to be realised in many other contexts, was based on a hierarchical spatial order. At the first glance, the most important characteristic of the spatial regime of milk collection traffic seems to be the fact that no transport route was overlapping another one. It was an efficient system without any oversupply on the one side or any undersupply on the other. The new transport network covered the whole territory.

citing Vogt, one of the Reichsbahn presidents, who believed that common interest and the interest of the Reichsbahn were naturally the same.

33 «The Royal Order», reprinted in: Royal Commission on Transport, Final Report, VII, VIII; citation VII.

34 Aldcroft, British Transport, esp. 30-95; A. Zatsch Staatsmacht und Motorisierung am Morgen des Industriezeitalters, Konstanz I993.

35 See, for example, Anonymous, «VI. - Between Two Systems. How to Get the Best from Both», in: The Railways. Six Special Articles together with Two
Leading Articles Reprinted from The Times, London I932, 26-29; K. G. Fenelon, Transport Co-ordination, London 1998 (original edition I929), Royal Commission on Transport, Final Report. A.F. Napp-Zinn, «Die Neugestaltung der Verkehrspolitik im nationalsozialistischen Deutschland», in: Jahrbücher für Nationalökonomie und Statistik I4I (I935), 22-52; C. Pirath, Verkehrseinheit und Verkehrspolitik, Berlin I935. See also Schlimm, «Verkehrseinheit». 
This important characteristic notwithstanding, the more interesting aspect of this transport regime is the hierarchy on which the system was based. It cannot be reduced to a simple centralisation pattern. In fact, the spatial regime was more complex because it was based on a multi-level hierarchy. Each individual farm was part of one (and only one) sector that was served by one lorry; each two or three of these sectors were related to one sub-centre. The result was a complex system of hierarchies and interconnections, which was not only able to exploit the whole territory but also to realise an economic order of transport without any competition.

The relationship between spatial aspects and co-operation problems lies in the fact that the main lines of competition did not run solely between collective and individual transport facilities, between regulated enterprises and free market economy, between «public» and «private» interest. Furthermore, the opposition between road and rail was also perceived as one of spatial effects: independent and private road transport served the short distance exploitation of space, while politically regulated rail transport was considered for long distances and the effective linkage of centres. Thus, the attempts to establish a co-ordinated transport economy were strongly linked to the idiosyncratic concept of spatial order which the transport discourse was based on. An important component of this underlying discursive structure was the fact that both forms of transport were seen as indispensable. ${ }^{36}$ Therefore, the aim was to establish a new balance between the different transport functions as well as transport facilities - and particularly not to bring the old railway monopoly back into being. The equilibrium could, according to the transport expertise, only be achieved in a strictly hierarchical system, in which the most important lines and the cheapest infrastructure were combined. ${ }^{37}$

All transport facilities were - according to the basic paradigm of transport studies - seen as a vital part of the overwhelming transport system; every part had thus to serve different tasks. Transport was not interpreted as a kind of space compression, as it is sometimes discussed in recent spatial theory. ${ }^{38}$ Instead, there were three different spatial functions of transport: connection, exploitation and structuring of space. All of

36 Anonymous, «An Open Letter to the Minister of Transport. A Great Opportunity for Sir Eric Geddes. The Institute of Transport, His Presidential Address», in: Modern Transport III (I920), 53, 2; M.-E. Feuchtinger, Der Verkehr im Wandel der Zeiten seit dem Jahre 1000. Studie auf Grund der Wirtschafts- und Verkehrsbeziehungen der früheren Reichsstadt Ulm an der Donau, Berlin I935, I20; E. MüllerHermann, Wettbewerb und Ordnung. Grundlage der Verkehrspolitik, Darmstadt I954, I2-I3; A. Schmitt, «Verkehrspolitik», in: A. Weber (ed.), Handels- und Verkehrspolitik. Binnenhandel - Verkehr - Außenhandel. Wirtschaftspolitik II, München, Leipzig I933, I47-286, 259-260; G. J. Walker, Road and Rail. An Enquiry into the Economics of Competition and State Control, London I942, I6o.
37 The whole discourse on transport competition was based on a fundamental diagnosis of a crisis, which made waiting for a natural balance impossible. In the contemporary crisis, waiting for a natural equilibrium would cause a severe waste of resources, which were constantly short. This diagnosis also found its way into the definition of unwanted competition: it was a «wasteful» one. R. J. Eaton, The Elements of Transport, London I936, 53 .

38 See W. Kaschuba, Die Überwindung der Distanz. Zeit und Raum in der europäischen Moderne, Frankfurt a. M. 2004; H. Rosa, Beschleunigung. Die Veränderung der Zeitstrukturen in der Moderne, Frankfurt a. M. 2005; P. Virilio, Revolutionen der Geschwindigkeit, Berlin I993. 
them had to be combined in the right way to achieve a rational social order. ${ }^{39}$ While there were means of transport whose abilities lay primarily in the linkage of centres (like mainline railways or air transport), other means seemed to be able to open up distinctive regions - light railways as well as lorries were discussed in this respect. To properly combine these abilities and effects it was crucial for correctly structuring the space - at a global as well as at regional level. Thus, transport experts had to organise transport facilities in such a way that the spatial effects of the different transport media were combined to realise an ideal spatial order.

This difficult task was based on the idea that a specific equilibrium between linking and exploiting transport facilities should be achieved. It was perceived as a great mistake of the nineteenth century that the railways, thus the facilities with the greatest capability of linking two centres, were developed without taking account of de-centralising transport media like light railways or road transport facilities. The furious process of urbanisation was the result, which seemed now irreversible..$^{40}$ Yet the other extreme was not an alternative either - the concentration on those transport facilities which served to stretch land would have led to the complete dissolution of all structures. A modern form of economy could not be envisaged without centres of commerce and production, and, moreover, to concentrate on de-centralising transport facilities would have been very costly given the lower effectiveness and higher costs of the area-serving facilities like lorries or light railways..$^{41}$ Even the construction of the Reichsautobahn was critically discussed in respect of its spatial effects. The showcase project of the nationalsocialist transport policy was suspected of causing new centralising processes. ${ }^{42}$

Thus, every transport system in a distinct space had to solve two different problems: it had to exploit the whole space and to avoid all uneconomic oversupplies simultaneously. This seemed to be possible only by a hierarchical order of the different transport facilities, in which the most flexible and lightest vehicles provided the lowest level of exploitation and the most non-elastic means of transport formed the «backbone» of transport system. ${ }^{43}$ Flexibility and elasticity were not only discussed as spatial capabili-

39 See, for example, R. Emerson, «The Choice of Transport for an Underdeveloped Territory», in: The Journal of the Institute of Transport 28 (I959), 4, II9-I2I; A. Liebmann, «Kleinbahnen», in: Jahr buch für Verkehrswissenschaft I (I9I3), 4, 42I-443; C. Pirath: Die Deutschen Verkehrsmittel in ihren Beziehungen zueinander (Reichsbahnbeamtenzeitung I937), University Archives Stuttgart (UAS), 89/5a.

40 K. Bergmann, Agrarromantik und Großstadtfeindschaft, Meisenheim am Glan I970; specifically on urban transport: D. Schott, «Suburbanizing the Masses for Profit or Welfare: Conflict and Cooperation between Private and Municipal Interests in German Cities, I890-I9I4», in: C. Divall /
W. Bond (eds.), Suburbanizing the Masses. Public Transport and Urban Development in Historical Perspective, Aldershot 2003, 79-99.

41 See C. Pirath, Die Verkehrsteilung Schiene-Strasse in landwirtschaftlichen Gebieten und ihre volkswirtschaftliche Bedeutung, Berlin et al. I954, 2.

42 C. Pirath, «Die Raumerschließung durch die Reichsautobahnen», in: Zeitschrift für Verkehrswissenschaft I5 (I938) 3/4, I8I-I93.

43 See K. G. Fenelon, Railway Economics, London I932, 2I7; O. Steinhoff, «Betriebspflicht und Tarifzwang», in: Verkehrstechnische Woche. Zeitschrift für das gesamte Verkehrswesen 2I (I927) I, I-5, 5 . 
ties - like the difference between rail bound and non-rail-bound means of transport, but also as economic ones. And, furthermore, all these differences followed the same lines. On the one hand, there were the privately owned road transport facilities, which were able to react flexibly to new transport requirements or volatile demands, on the other hand the non-elastic main railways.

To sum up, the hierarchy between the transport means that structured all attempts to solve the problem of transport co-ordination in the inter-war years was a spatial, a technical and an economic one. And I would add: the hierarchical order was also a political one. Publicly controlled railways were seen as the backbone of the whole transport system. They were first and foremost transport facilities that the public administration was able to regulate, and indeed, they were largely governed in a topdown-manner. As a consequence of their technical, organisational and legal specifics, they predetermined the spatial pattern of transport policy. Transport experts were profoundly convinced that this could be considered the natural way of governing spaces by transport systems. Yet apart from the top-down regulation, most transport experts claimed that transport could not be planned entirely. They described their field of expertise as a highly dynamic sector, which could only be managed by a mixture of planning and evolution.

\section{Margins of Self-organisation}

The core feature of the Cornish success story was the evolution of an even more perfect and smooth transport co-ordination, which started immediately after having finished the planning and implementing process. The system that had been introduced by experts of the railway company proved to be sufficiently flexible to provide margins of self-organisation and development.

The reader of transport experts' texts from the inter-war years will encounter those margins of development quite often - at least more often than most readers would expect when working on a planning discipline at the high tide of authoritarian planning practices. Beyond the fixed lines of inflexible transport infrastructure, many transport experts expected potentials of development. In some cases, this expectation was limited to «new» transport branches, that is, air transport or the «young» road transport. ${ }^{44}$ Their regulation should leave leeway for development, which would eventually serve the common interest. This argument was predominantly used by representatives of road transport companies and the automobile industry, since they were in the first place interested in avoiding all regulation attempts for the road transport sector. ${ }^{45}$

44 See C. Pirath: Die Entwicklung des Weltluftverkehrs in seinen Beziehungen zur Eisenbahn. 13.02.1929, UAS 89/Io; C. Pirath / M.-E. Feuchtinger, Der Kraftfahrzeugbedarf für den Wiederaufbau und die Erhaltung der deutschen Wirtschaft [typescript], Stuttgart I946.
45 W. Scholz, «Vortrag aus Sicht der Automobilindustrie», in: A. F. Napp-Zinn (ed.), Eisenbahn und Kraftwagen. Verhandlungen auf der von dem Verein zur Wahrung der gemeinsamen wirtschaftlichen Interessen in Rheinland und Westfalen und dem Institut für Verkehrswissenschaft an der Universität Köln am 
Nonetheless, proponents of the railway system - like most of the German transport experts- also used this argument in order to achieve that some margins were left free of regulation. These margins were normally located at the lowest level of the spatial order, that is, in the sphere of local transport. Local transport relations were hardly schedulable because of their high volatility, and they seemed less pivotal for the national economy than long-distance traffic relations.

Here again, the strong hierarchical relationship between the different transport facilities can be observed which underlay the transport experts' discourse. Central traffic needs regarding long distances had to be satisfied, and this required a rational and central planning process. Otherwise, this backbone of traffic system would have overlapped in the more crowded areas and the less inhabited (or industrialised) regions would have been neglected. For a balanced network, central planning accordingly seemed indispensable. In addition to the main lines of transport, a need for feeder services to explore the regions around was expressed. Here, the special abilities of private road transport came into play. ${ }^{46}$

This hierarchical division of labour had also political implications. In both countries, the freight transport industry was brought under a strict regulation system in order to ensure the co-ordination of road and rail in the early I930s. Under this regulation system, railways were supposed to manage the long distance traffic, and the road transport industry should carry out the short distance traffic and feeder services. To ensure this division of labour, only the local range remained free from regulation (and became thereby a sphere of competition), while the regional and national transport was subjected to a strict system of concessions. Long distance freight routes by lorries were permitted only to the extent that they did not compete with rail routes. ${ }^{47}$ The road transport industry may have been perceived as a necessary element in transport, but still subordinate to railways.

\section{Conclusion}

My main interest in this contribution was to analyse the every-day and small-scale planning processes with the objective of providing insight into how they may contribute to our understanding of inter-war planning processes. My analysis results in a bundle of propositions that could partly adjust our picture of planning in the first half of the twentieth century. I intended to show that planning in this period was by no means characterised solely by large-scale, utopian or radical planning attempts. If one analyses the «normal state» instead of the «state of exception», as Timo Luks recently suggested, the scope of intervention practices in this era is widened substantially. ${ }^{48}$

27. Mai 1930 in Düsseldorf veranstalteten Verkehrstagung; mit Anschluß einer verkehrwissenschaftlichen Kritik, Köln I93I, 36-64.

46 See K. G. Fenelon, «Some Aspects of Road and Rail Transport. Methods of Effecting Co-ordina- tion», in: Modern Transport 20 (I928) 496, 9-IO.

47 Filarski / Mom, Transport Policy, I56-I60; Schlimm, Ordnungen, 216-22I; Sjöblom, «Shift».

48 T. Luks, «Eine Moderne im Normalzustand. Ordnungsdenken und Social Engineering in der ers- 
First of all, the expert cultures in Great Britain and Germany show very similar representations and perceptions of space and spatial order. While many recent analyses stress the practices of spatial homogenisation and separation, the analysis of transport expertise has shown that we can find strong efforts to bring space into a new structure by implementing a space hierarchy.

This approach had two prerequisites. Firstly, the differentiation of spaces was only possible due to a holistic representation of transport. Transport was seen as an instrument for re-stabilising the (perceived) chaotic and destabilised transport and social order at the same time, and it made an integrated planning process necessary that had to take into account all existing means of transport. Finally, this idea ensured the coherence in spite of divisions of labour and space.

The second prerequisite was the interlocking of a central, top-down planning process with bottom-up processes of self-organisation and evolution on a lower level. Planning and self-organisation, which had long been considered as antagonists, particularly concerning the supposed anti-liberal era between the wars, ${ }^{49}$ were not seen as inseparable approaches for transport experts (and perhaps other protagonists) between the wars. Nonetheless, these two approaches were placed in a clear hierarchical order: selforganisation was only tolerated or desirable a) in consigned spaces, on a local or regional level, and b) only on condition that all undertakings were serving the higher goal of transport.

Beyond these similarities, the two national examples show different forms of acceptance for the (supposed) essential spheres of self-organisation. The German case shows an attitude of mere tolerance because complete planning was considered impossible, while British experts (and transport politicians) expressed even their willingness to integrate self-organised negotiations between different transport undertakings into the planning process..$^{50}$ These rather participatory forms of planning were inconceivable in Germany - despite many corporative political structures in Weimar Germany..$^{11}$

These characteristics of transport planning in both countries differ in many respects from the forms of authoritarian and top-down planning that we know from the analysis of large-scale projects. Does that mean that transport planning was a kind of asynchrony in history, maybe even pointing towards mere postmodern forms of planning and regulation?

ten Hälfte des 20. Jahrhunderts», in: Österreichische Zeitschrift für Geschichtswissenschaft 23 (20I2) 2, $15-38$.

49 See A. Doering-Manteuffel, «Die deutsche Geschichte in den Zeitbögen des 20. Jahrhunderts», in: Vierteljahrshefte für Zeitgeschichte 62 (20I4), $32 \mathrm{I}-348$.

50 A. Schlimm, «Social Engineers in Transport Poli- cy. Co-ordination Efforts in Governmental Commissions in Britain during the Interwar Years», in: G. Duc et. al. (eds.), Histoire des Transports et de la Mobilité. Entre concurrence modale et Coordination (de 1918 à nos jours), Neuchâtel 20I4, I3I-I46.

51 See A. Rehling, Konfliktstrategie und Konsenssuche in der Krise. Von der Zentralarbeitsgemeinschaft zur Konzertierten Aktion, Baden-Baden 20 II. 
In fact, I would suggest the opposite. The attempts to regulate and stabilise a social and transport order which can be reconstructed through an analysis of transport expertise between the wars were by no means post-modern. The strict hierarchy of topdown and bottom-up regulations points to a high modernist ideology as well as the exalted position of the expert. Only small ranges of self-organisation were left between the fixed spheres of rational and efficient transport regulation. Therefore, I would propose analysing these forms of planning attempts also as powerful and high modernist approaches that are related to a distinct social order which social experts were asked to establish. Even if these forms of every-day and low-scale planning were by no means analogous to those interventions that tried to realise a new and utopian social order by using extreme, authoritarian forms of power, they still influenced social life considerably. These «normal state» planning processes attempted to re-establish a threatened order in the normal spaces of society, which became another challenge for planners, and that implied other forms of power and force. Moreover, these planning processes were often accompanied by strict regulations, disciplining norms and strong hierarchies.

\section{Planning Order and Self-Organisation. The Regulation of Competition and Spatial Relations in Inter-War Transport Expertise}

Planning practices in high modernity are often analysed as authoritarian and topdown interventions. This interpretation derives from the concentration on largescale planning projects. By investigating small-scale and every-day transport planning examples, this article tries to enhance our understanding of high modern planning practices. Transport planning during the inter-war years meant to establish a transport regime in which all means of transport were put into a rational relation to each other. This was only possible by building up a spatial order in which different spatial functions - connecting places, opening up regions and structuring spaces - were placed in hierarchical order. Hence, the planned spaces often displayed a hierarchy of top-down and bottom-up organisational patterns. This should by no means be regarded as a form of pre-postmodern fascination for self-organisation of order out of chaos. On the contrary, these planning projects, too, reveal strictly defined power relations, even if their objectives and methods cannot be put on a par with famous large-scale projects.

Anette Schlimm

Ludwig-Maximilians-Universität München Historisches Seminar, Neueste Geschichte und Zeitgeschichte Geschwister-Scholl-Platz 1 D-80539 München e-mail:a.schlimm@Imu.de 


\section{Stefan Couperus}

\section{Experimental Planning after the Blitz. Non-governmental Planning Initiatives and Post-war Reconstruction in Coventry and Rotterdam, I940-I955}

The history of blitzed cities in the Second World War allows for a rather evident articulation of an experimental space. The destructive effects of aerial bombardments incited an avalanche of ideas and ideals about the planned redevelopment of cities such as London, Coventry, Plymouth, Rotterdam, Le Havre, Hamburg, Dresden and Warsaw.

A somewhat provocative, but nevertheless empirically supported reading of wartime destructions due to bombardments is that they were considered «a blessing in disguise.» ${ }^{1}$ Other than interwar municipal policy schemes, political reform and town planning projects, bombs were capable of removing the tenacious impediments to modernist urban reform, such as slums, blight areas, vested interests, old property rights, and social misfits who inhabited the inner city alleys and districts. Moreover, obliteration by bombs allowed for subsequent clearance of (sometimes undamaged) adjacent structures and spurred a revision of the physical organisation of the urban environment as a whole. This perceived window of opportunity to act upon the city with unprecedented energy and swiftness was accompanied by the establishment of a governance structure in which urban planners obtained a pivotal position. ${ }^{2}$

The reconstruction of blitzed cities can not only be regarded as an experimental space but also fits the temporal framework of an experimental interlude during which a number of planning ideas and thoughts were advanced or even acted out. From the first post-apocalyptic weeks until the promulgation of the grand post-war structures of urban planning, housing and welfare from the late i940s onward, the locally felt urgencies of recovery fostered a series of planning experiments. Most of

1 On this interpretation see: J. Düwel / N. Gutschow (eds.), A Blessing in Disguise. War and Town Planning in Europe, 1940-I945, Berlin 2013.

2 Influential studies include: W. Durth / N. Gutschow, Träume in Trümmern: Stadtplanung 1940-1950, Munich I993; J. Düwel, 1945: Krieg - Zerstörung Aufbau, Berlin I995; D. Voldman, La Reconstruc- tion Des Villes Françaises de 1940 à 1954: Histoire D'une Politique, Paris I997; J. Hasegawa, Replanning the Blitzed City Centre: a Comparative Study of Bristol, Coventry and Southampton 1941-1950, Buckingham I992; J. M. Diefendorf, In the Wake of War: The Reconstruction of German Cities after World War II, Oxford I993; K. Bosma / C. Wagenaar 
these experiments were initiated by (local) authorities. However, with local authorities awaiting national directives for action, the voluntary sector produced a series of planning ideas too.

This article is in line with recent historiography that acknowledges the wider range of non-governmental actors, discourses and understandings of modernist planning in blitzed cities in post-war Europe. Further adhering to Dennis Sweeney's recent call to approach modernity from the perspective of the «heterogeneous and multiple rationalities of social reform projects and their immanence», this article highlights two nongovernmental experiments in community planning in the blitzed cities of Coventry and Rotterdam that emerged from the local voluntary sector. ${ }^{3}$ In the case of Coventry the Family Health Club and Housing Society strove to plan and build a self-sufficient, almost autarchic community estate at the outskirts of the city. In the case of Rotterdam, the Rotterdamsche Gemeenschap directed its energy towards the establishment of an alternative socio-political set-up, which departed from the neighbourhood level.

Both experiments focused on promoting alternative visions of post-war urban society and were conceived and partly executed outside of the authorised redevelopment plans, revealing their own rationalities and planning practices. Both projects had to cope with the hesitance and unpredictability that characterised urban politics and governance in the I940s.

This article argues that the planning of blitzed cities was not monopolised by authorised planners and administrators, but also included voluntary, private initiatives that emerged during the experimental interlude of the I940s. As such, this analysis stretches beyond the recently addressed theme of popular participation and consultation in post-war urban planning. It stresses the impact of private initiatives in reconstruction planning in the transitional stage between wartime crisis politics and the planned city in the era of post-war welfarism. Despite the fact that both projects failed to come to full fruition, they disclose a clear experimental outlook on the redevelopment of urban society after large-scale destruction and demolition.

(eds.), Een geruisloze doorbraak. De geschiedenis van architectuur en stedebouw tijdens de bezetting en de wederopbouw van Nederland, Rotterdam I995 J. M. Diefendorf (ed.), Rebuilding Europe's Bombed Cities, London I990; C. Wagenaar, Welvaartsstad in wording. De wederopbouw van Rotterdam, 19401952, Rotterdam I993.

3 D. Sweeney, «Modernity» and the Making of Social Order in Twentieth-Century Europe», in: Contemporary European History 23 (2014), 209-224 S. Goebel / D. Keene (eds.), Cities into Battlefields: Metropolitan Scenarios, Experiences and Commemorations of Total War, Aldershot 20II; M. Clapson /
P. J. Larkham (eds.), The Blitz and Its Legacy: Wartime Destruction to Post-war Reconstruction, Aldershot 2013; S. E. Cowan, Technocracy, Democracy and Publicity: Public Consultation and British Planning, 1939-1951, PhD thesis University of California, 20Iо; G. Wagner-Kyora (ed.), Wiederaufbau europäischer Städte: Rekonstruktionen, die Moderne und die lokale Identitätspolitik seit 1945, Stuttgart 20I4; P. J. Larkham / E. Erdem (eds.), Alternative Visions of Post-War Reconstruction: Creating the Modern Townscape, London 2015. 


\section{Rebuilding Post-war Coventry}

After the devastating German air raids in 1940, the booming industrial city of Coventry was subjected to the immediacy of recovery and reconstruction. ${ }^{4}$ Much of the inner city had been turned into ashes and housing shortages subsequently skyrocketed well into the I950s. The modernist city architect Donald Gibson took up the physical reconstruction of the blitzed areas as soon as the debris was removed from the streets. ${ }^{5}$ Coventry gradually became the symbol of post-war recovery in Britain: it was hailed as a modern industrial city, whose population, despite continuing problems with mass housing, experienced one of the highest degrees of affluence in Britain in the I950s. ${ }^{6}$ In post-war propagandist discourse Coventry became «a twentieth century icon» of British resilience and prosperity whose esteem stretched beyond the British isle. ${ }^{7}$

A firmly entrenched Labour and Trade Union hegemony shaped Coventry's political culture during the I940s, although other ideological groups secured a sustainable position in urban governance too. ${ }^{8}$ Backed by the relatively affluent working class, Labour officials were at the vanguard of emergency politics after the blitz and dominated the subsequent redevelopment of the city. Fitting the mounting narrative of Labour's post-war New Jerusalem, Coventry seemed to fulfil the promise of a «better Britain»: it swiftly presented a bold, modernist reconstruction plan, which harked back to pre-war initiatives of modernist urban regeneration, and was able to sustain high levels of welfare as the austerity of the I940s yielded to consumerist affluence in the I950s.

Linking it to the wider context of British reconstruction politics, Coventry may be seen as a showcase of Clement Attlee's post-war reformist Labour administration, which aspired to «plan from the ground up» and produced the centralist frameworks of post-war welfarism relating, among others, to health care, housing and economic regulation. ${ }^{9}$ This national planning agenda, too, provoked criticism on the Labour government that was allegedly employing a mode of «socialist authoritarianism». Political opponents, intellectuals but also representatives from the voluntary sector accused Labour of according primacy to its administrative and planning apparatus and thus employing a system of state planning that was «inefficient, unjust and undemo-

4 T. Mason / N. Tiratsoo, «People, Politics and Planning: The Reconstruction of Coventry's City Centre, I940-53», in: Diefendorf, Rebuilding Europe's Bombed Cities, 94-II3; N. Tiratsoo / T. Mason / T. Matsumura, Urban Reconstruction in Britain and Japan, 19451955: Dreams, Plans and Realities, Luton 2002.

5 S. H. Walford, Architecture in Tension: an Examination of the Position of the Architect in the Private and Public Sectors, Focusing on the Training and Careers of Sir Basis Spence (1907-1976) and Sir Donald Gibson (1908-1991), PhD thesis University of Warwick, 2009 .

6 On this see: N. Tiratsoo, Reconstruction, Affluence and Labour Politics: Coventry, 1945-1960, London I990.

7 A. Smith, The City of Coventry: a Twentieth Century Icon, London 2006; L. Campbell, «Paper Dream City / Modern Monument: Donald Gibson and Coventry», in: I. Boyd Whyte (ed.), Man-Made Future: Planning, Education and Design in Mid-Twentieth-Century Britain, London 2007, I2I-I44.

8 Tiratsoo, Reconstruction, 46-52.

9 M. J. Daunton, Wealth and Welfare: an Economic and Social History of Britain, 1851-1951, Oxford 2007, 594; K. O. Morgan, Britain Since 1945: The People's Peace, Oxford 200I, 232. 
cratic». ${ }^{10}$ Recent historiography has however shown that the perceived distance between Labour-endorsed expert planners and the people should not be taken at face value. Nick Tiratsoo has convincingly argued that the bold planning statements in postwar Britain do not reflect the practices in which public opinion, national policy as well as wishes from the citizenry constituted the complex nexus of British planning. ${ }^{11}$ More recently, Susan Cowan has systematically disclosed the wide range of public consultation practices that paralleled the design and implementation of modernist town plans in Britain's blitzed cities. ${ }^{12}$ The work of Peter Larkham and Keith Lilley, among others, stresses that officials and planners were acutely aware of the public, which translated into a series of promotional strategies, for instance the public exhibitions of plans. ${ }^{13}$

In the particular case of Coventry, Tiratsoo has underlined the political pluralism that, despite Labour's dominance, generated substantial political debate, resulting in amendments to Labour's policy agenda and fluctuations in electoral appeal. ${ }^{14}$ Other studies have also probed into the social aspects of wartime and post-war life in Coventry and elsewhere, allowing for less partisan narratives of reconstruction politics in the I940s and I950s. ${ }^{15}$

The case study presented here entails a private endeavour of community planning during the experimental interlude between the blitz and the coordinated reconstruction of Coventry from the late I940s onwards. It shows how a private planning project emerged from within Coventry's civil society that became known as the Family Health Club Housing Society Coventry (FHC)and promoted a type of community and mode of citizenship that increasingly conflicted with the post-war hegemonic agendas of British recovery.

\section{Positive Health, Housing and Democracy: The Idea of the Family Health Club}

In August I944, the radiologist Kenneth E. Barlow, together with a group of prominent Coventry citizens, founded the Family Health Club Housing Society Coventry, which was registered under the Provident Societies Act in April $1945 .{ }^{16}$ Under this banner, a

10 Cited in: N. Tiratsoo, «New Vistas»: The Labour Party, Citizenship and the Built Environment in the I940S», in: R. Weight / A. Beach (eds.), The Right to Belong: Citizenship and National Identity in Britain, 1930-1960, London I998, I37.

11 N. Tiratsoo, «The Reconstruction of Blitzed British Cities, I945-55: Myths and Reality», in: Contemporary British History I4 (2000), 27-44.

12 Cowan, Planning to the People.

13 P. J. Larkham / K. D. Lilley, «Exhibiting the City: Planning Ideas and Public Involvement in Wartime and Early Post-War Britain», in: Town Planning Review 83 (20I2), 648-668; P. J. Larkham / K. D. Lilley, «Plans, Planners and City Images: Place Promotion and Civic Boosterism in British Reconstruction Planning», in: Urban History 30
(2003), I83-205; P. J. Larkham, «Selling the Future City: Images in UK Post-War Reconstruction Plans», in: Whyte, Man-Made Future; K. D. Lilley, «On Display: Planning Exhibitions as Civic Propaganda or Public Consultation?», in: Planning History 25 (2003), 3-8.

14 Tiratsoo, Reconstruction, passim.

15 R. Cherrington, Not Just Beer and Bingo! A Social History of Working Men's Clubs, [S.1.] 20I2; I. Buruma, Year Zero: a History of 1945, London 2013; D. Kynaston, Austerity Britain, 1945-1951, London 2007; J. Grindrod, Concretopia: a Journey Around the Rebuilding of Post-war Britain, Brecon 2013.

16 National Archives (Public Record Office), FS 35/80, Family Health Club Housing Society (Coventry) Limited. 
group of Coventrians embarked on a particular kind of community planning that was informed by three categories: health, home and democracy. These three elements were not preconceived building blocks for a community, but were to be discovered through experiment, which made the FHC «an experimental community» first and foremost. ${ }^{17}$

The «social biology» often referred to in FHC publications, was an unimpaired subscription to what was called «the positive health» movement stemming from the interwar Peckham experiment at the Pioneer Health Centre in London. Barlow, who published regularly on behalf of the FHC, represented an intellectual current amongst British medics who explained health as a social category rather than a medical, pathological one. Health, argued Barlow, was about prevention and promotion rather than pathology: «Neither health nor the circumstances which are likely to promote health, receive adequate consideration, either by the medical profession or by the so-called Ministry of Health.» ${ }^{18}$ An annual family health overhaul, for instance, was a key feature of the FHC's health programme, as were the social activities in the planned health centre. But the FHC also proposed some feasible additions in order to sustain family health, such as securing good nutrition by practising organic farming.

These and other communal additions to the project, most importantly the ninestorey flat complexes, provoked critique from the milieu of urbanists and planners. The famous cultural sociologist Lewis Mumford, who knew Barlow as his former assistant, conveyed his doubts about the communal nature of the Coventry project to his friend, the urbanist Frederic J. Osborn. ${ }^{19}$ Scott Williamson, the leading figure of the Peckham experiment in London, was concerned with the Coventry experiment too, as it resorted to housing solutions rather than to what he called «grow homes, and not build houses». ${ }^{20}$ High-rises denied the biological order of the family, the key social unit from which, in the holistic language of Williamson, «the heart of the home» would develop.

The title of the Coventry project indeed revealed its double agenda: it was as much about family health promotion as it was about housing. This combination of «positive health» and housing was a strategy to legitimise the FHC within the context of Coventry's post-blitz demands of reconstruction. The pressing housing shortages would elicit enthusiasm for private initiatives that would be able to contribute to a solution. Thus, regardless of their holistic discourse on the family and the home, the FHC in essence

17 Wellcome Library (hereafter WL), Archive Peckham Health Centre (hereafter PHC), B.5.25.2, Address by Kenneth Barlow for the West Midland Group on Post War Reconstruction and Planning (undated); K. E. Barlow, A Home of Their Own, London I946, 85 .

18 The Medical Press and Circular, 3 April I946.

19 M. R. Hughes, The Letters of Lewis Mumford and Frederic J. Osborn: a Transatlantic Dialogue, 19381970, Bath I97I, I8I; Barlow had been Mumford's personal assistant after he had assisted the famous Patrick Geddes with editing The Sociological Review. See: E. Kirby, «Obituary - Kenneth Elliott Barlow, FRCR, DMR, MRCS, LRCS», in: Nutrition and Health 50 (200I), 75-76.

20 WL, PHC, B.5.25.I, G.S. Williamson to Family Health Centre Housing Society Coventy, [I945]; J. Lewis / B. Brookes, «A Reassessment of the Work of the Peckham Centre, I936-I95I», in: Milbank Memorial Fund Quarterly, 6I (I983), 307-350, 323. 
offered a much-wanted asset: dwellings. However, positive health and housing could only contribute to the creation of a sustainable community if it was cemented by democratic governance: people needed to have a say in the way in which health and housing were to be guaranteed.

The FHC explicitly sought to connect to the burgeoning gospel of democracy and democratic citizenship that developed in post-war Britain and linked up with earlier debates. ${ }^{21}$ Or as Barlow defined the essence of the experimental interlude: «The critical experiment is an experiment in democracy.» ${ }^{22}$ This democratic experiment entailed, above all, a high degree of citizen initiative and collaboration. ${ }^{23}$ The FHC, consequently, depended upon «the initiative of its members», which an early brochure stated, was «characteristically British and democratic». ${ }^{24}$ In front of a group of regional planners, Barlow argued: «The experiment consists of seeing just what the community will make of those opportunities and of itself in the setting which those opportunities afford.» 25 As such, Barlow believed the FHC was «far more radical and far more democratic» than any project the City Council of Coventry had promoted. ${ }^{26}$

Planning, against the backdrop of this democratic conception of active citizenship, then amounted to something entirely different than state-led planning by experts and administrators: «To make a beginning with the cultivation of communities, the people and planners must come together. But to get the results that our communities require, the initiative and the purpose of the experiment must spring from the people and not from the planner [...] when the planner decides that is bureaucracy. When the people decide that is democracy.» ${ }^{27}$ The Observer wrote in a similar vein, «the Coventry project [...] is a non-profit-making enterprise in which local people, instead of looking for some Governmental authority to plan for them, are coming together to plan their own housing and community life». ${ }^{28}$ Evidently, the FHC's grassroots initiative was consciously juxtaposed to what was understood as «socialist authoritarianism» and seen as the solution to reinvigorate the «castrated communities» of Britain - in the words of the Secretary of State Health, Aneurin Bevan. ${ }^{29}$

Members of the FHC publicly distanced themselves from Labour's post-war planning agendas, particularly with regard to the emerging National Health Service (NHS).

21 For a recent, vivid impression of the celebration of victory and democratic discourse in post-I945 Britain see the film documentary by K. Loach, The Spirit of ' 45 (2013). For pre-war thoughts on citizenship in Britian see: J. Harris, «Political Thought and the Welfare State, I870-I940: An Intellectual Framework for British Social Polity», in: Past \& Present I35 (I992) I, II6-I4I.

22 Barlow, A Home, 85.

23 WL, PHC, B.5.25.2, The Family Health Club and Housing Society (Coventry) Ltd. (undated).

24 Ibid.

25 WL, PHC, B.5.25.2, Address by Kenneth Barlow for the West Midland Group on Post War Reconstruction and Planning (undated)

26 K. E. Barlow, The Family Health Club, unpublished and undated manuscript, 45.

27 Cited in: M. Brooks, The Family Health Club Housing Society (Coventry) Ltd 1945-1956, MA thesis University of Warwick I987, 45.

28 The Observer, 29 July I945.

29 Quoted in: S. Fielding / P. Thompson / N. Tiratsoo, «England Arise!»: The Labour Party and Popular Politics in 1940s Britain, Manchester I995, I04. 
The head of the management committee stated in a local newspaper that «[s]tate control means the patients having no direct share in the administration of the new service [...] Health service should preserve for both patient and doctor freed from bureaucratic regimentation.» ${ }^{30}$

In his study on Labour dominated reconstruction politics in Coventry, Tiratsoo sees the FHC as part of the «pressure of the trade unions or others on the left». ${ }^{31}$ However, labelling the FHC as leftist is problematic when taking its ambiguity towards Labour's agenda of centralist welfarism (e.g. the NHS) and the varying backgrounds of its members into account. Alongside working class families, one can find engineering workers, doctors, farmers, teachers, nurses and clerical workers within the organisation. The management committee comprised members of the Conservative and Labour parties alike, but also, to a lesser extent, Christian Socialists and Communist Party members. ${ }^{32}$

\section{The Rise and Demise of a Newly Planned Community in Practice}

The aims, ambitions and language of the FHC's alternative route of community planning were in place by the end of I945. The realisation of the project, however, proved far more troublesome. After having generated sufficient enthusiasm for the FHC among Coventry's families (350 families had allegedly registered, but numbers of 657 were mentioned in early I948), four discussion groups (the nature of family life according to the Peckham experiment, agriculture and nutrition, social activities, and housing and finance) were installed to further the plan.

The FHC's ambitions were clear: «We want so to associate 2000 families that they will constitute a community that will be capable of creating a neighbourhood which will effectively be their own: wherein they themselves will meet their own housing needs, where they will create their own health centre as the pivot of their community and where they will provide for their own most critical nutritional needs.» ${ }^{33}$ A series of lectures and meetings in Coventry and its surroundings spurred enthusiasm. ${ }^{34}$ Margaret Brooks has restated the perceived prospects of interviewed FHC members: «The estate [...] would be compact and totally self-sufficient with its own modern shops «solely for pedestrians», schools, churches, cinemas, playing fields, amenity land and own farm, and underground parking facilities. The houses would have their own gardens and to ensure privacy and maximum sunlight, all blocks of building would be staggered. [In the Health Centre] would be a swimming-bath, the gymnasium, the icerink, the theatre, dance-halls, social rooms for indoor games nurseries for young children and self-service cafeteria.» 35

30 Brooks, The Family Health Club, 67.

31 Tiratsoo, Reconstruction, 47.

32 Coventry Evening Telegraph, 4 June I947.

33 WL, PHC B.5.25.2, Publications K. E. Barlow I944-

I948, note I944 [no further date specification].

34 I. H. Pearse, The Quality of Life: the Peckham Ap- proach to Human Ethology, Edinburgh 1979, I79, appendix I3; Barlow, A Home, 86.

35 Brooks, The Family Health Club, 68-69. 
The FHC's energetic frontman, Barlow, was constantly looking for money to finance the purchase of land, as shareholders had only generated a capital of 132 pounds by August 1945. In early I946 Barlow had secured a mortgage from the Liverpool Victoria Friendly Society. ${ }^{36}$ This enabled the FHC to purchase an estate just east of the city of Coventry, in Binley. The acquired land had an additional challenge to it. It had not been cultivated for years and the two existing farms (Binley Common farm and Roseycombe farm) were largely idle. The FHC's aim was to prevent the property (Brandon Wood as the $46 \mathrm{I}$ acre estate was mostly referred to) from «degenerating into a rural slum» and to turn it into a thriving community with its own agricultural food production. ${ }^{37}$

Although most Coventry City and Rugby Rural District officials were enthusiastic about the plan, no political or financial support was gained as long as the FHC could not submit fully detailed plans. ${ }^{38}$ With the help of Arcon architects, particularly the famous prefab architect Raglan Squire (who charged a reduced rate), the plans progressed from spring 1946 onward.

Meanwhile, the first feasible activities of the FHC were initiated. Members organised a host of social activities on the estate. Some arable farming (organic growing) was undertaken and Barlow's family, together with two farm workers and a farm bailiff moved permanently to the Binley Common Farmhouse. ${ }^{39}$ The citizens of Coventry became increasingly aware of the project as a ten-day exhibition at Trinity Hall was opened on July 6, I946. It displayed the spatial layout and the interiors of the buildings. Lewis Mumford gave a stimulating opening address, in which he declared that the FHC started «at a point which the town planner and Government bodies never reached - the family»..$^{40}$ The local press published positively on the FHC: «British people are showing signs of turning social experimenters, working out for themselves new patterns for living, working or playing together [...] The really important thing is that they are being tried, not under official inspiration or to order, but spontaneously.» ${ }^{41}$

Finally, on 7 March 1947, the FHC submitted its plans to the local and regional authorities. The first stage of the housing plan would provide 139 dwellings, including the first complex of 68 flats. All designs had been subjected to FHC members' opinion. The entire Brandon Wood Estate Scheme was sketched out too. It included housing for all income groups and family compositions, including single elderly people, amounting to 2000 homes for about 8000 people in total. ${ }^{42}$

The submission of the plan proved to be the starting point of a series of lengthy discussions and negotiations with all authorities over the approval and progress of the scheme. Coventry's Housing Committee refused to give final consent as long as it was unclear whether the scheme would interfere with the pending municipal housing pro-

36 Ibid., 52

37 Cited in: ibid., 59

38 Ibid., 6r.

39 Ibid., 85-II5.

40 Cited in: ibid., 77.
41 Cited in: ibid., 65.

42 Coventry History Centre, CCD/AP/I/36/5/52 and 53, Family Health Club Housing Society (Coventry) Brandon Wood Estate layout plan, I5 September I947. 
gramme. ${ }^{43}$ Coventry was still awaiting government regulations on the allocations of labour and materials for public and private housing enterprises.

Lying just outside Coventry, the territory of the FHC fell under the jurisdiction of the Rugby Rural District Council and the Warwick County Council. However, the new Town and Country Planning Act of I947, effectuated on I July 1948, reinforced the Coventry City Council as the responsible authority for planning in the particular area of Brandon Wood. ${ }^{44}$ Initially promising some financial support, the Rugby Rural District Council fuelled a seemingly minor debate over the height of the housing complexes. On behalf of the FHC, Barlow argued that the preservation of farmland, so necessary in the context of food shortages, nutrition and the lack of buying power to import food from abroad, called for the inclusion of nine-storey high-rises in the plan. In a meeting with the Planning and Redevelopment Committee of Coventry in June I947, Barlow persuaded the committee members. The famous Labour alderman George Hodgkinson recalled: «Some of us felt a little adventurous [...] We were prepared to make an experiment.» ${ }^{45}$ However, ultimately the Rugby authorities were supported in their rejection of the high-rises in such a rural environment. The Coventry City Council overruled all political support by disapproving of the scheme. No «skyscrapers» were to emerge in the rural area of Brandon Wood. Hodgkinson, a persistent supporter of the FHC, concluded: «Some of us felt a little adventurous apparently, we were in fact being revolutionary.» 46

A few months later, the FHC's appeal to the minister of Town and Country Planning proved unsuccessful too. ${ }^{47}$ A new building request for farm cottages was rejected in 1948 - only the construction of two proof buildings was permitted. ${ }^{48}$ Moreover, new food regulations prohibited the sale of fresh, unpasteurised milk from the farm directly to the public. Even the planned annual health overhaul, which was initiated from October I949 onward, could not be organised without the assistance of the British Medical Association in Coventry; the intended health centre would never be built. 49

The FHC's vigour was smothered by the new political realities of the late I940s: national legislation and regulation narrowed the scope of private initiatives, whereas local and regional authorities promoted their own schemes and agendas in the new frameworks of housing, planning and health. Consequently, the FHC had to accept disappointment as their plans for housing, food production and amenities were largely crushed by state planning programmes and local Labour opposition, a conclusion Barlow was willing to accept acrimoniously only in hindsight. ${ }^{50}$

43 Brooks, The Family Health Club, 57.

44 Tiratsoo, Reconstruction, 39.

45 Brooks, The Family Health Club, 9I.

46 Cited in: ibid., 97.

47 Ibid., I05.

48 K. E. Barlow, Recognising Health, Plymouth I988, II7; The Family Health Club Review, 25 December I948.
49 P. Conford, The Development of the Organic Network: Linking People and Themes, 1945-95, Edinburgh 20II, I73-I75.

50 Barlow, Recognising health, II9; Barlow, The Family Health Club, I6o. 
In the early I950s, the FHC did not amount to more than the family health overhaul, some meetings of its board members and the publication of the Family Health Club Review. The farming results in Brandon Wood proved disappointing, inciting Barlow to fire the farm bailiff who was incapable of organising the farm on «business like lines». ${ }^{51}$ The farms were put up for sale not much later. The FHC solely continued its social activities, albeit on a modest scale. In 1956 , after more than half a decade of relative idleness, the formal bankruptcy of the FHC was inevitable. ${ }^{52}$

The FHC adhered to a fundamentally different relation between the planners and the planned compared to subordinate role citizens played in the design of the formal reconstruction plans. After the FHC had lost its momentum, this relation continued to resonate in Coventry's reconstruction politics. For instance, the sociologist Leo Kuper, hired by the Coventry municipality to pursue social surveys, recognised the value that the FHC had attached to the people's expressions of their needs and wishes. In his final recommendations Kuper wrote: «Our final suggestion is therefore to shift the emphasis from the physical determinism of the expert bureaucratic plan to the activities of the residents themselves.» ${ }^{53}$ Kuper explicitly declared his indebtedness to the FHC, as it had promoted participation in planning «not only in the actual plan» but also as a later stage during which «a share in the responsibility of the neighbourhood» was projected. ${ }^{54}$

\section{Rebuilding Post-war Rotterdam}

One year earlier, another experiment in community planning had also come to an end in Rotterdam, the heaviest bombed Dutch city during the Second World War. Rotterdam's inner city was completely destroyed by German bombs on I4 May I940. Other bombardments and German sabotage followed during the war causing more damage in residential and port districts.

As was the case in Coventry, Rotterdam's reconstruction frenzy amounted to bold modernist projections of a completely reshaped inner city. The demolitions ushered in an outburst of urbanists' ambitions, reinforcing their interwar modernist vistas for the resurrection of «the world port city». ${ }^{55}$ Reconstruction thought prompted an instant rivalry between various competing local groups of modernist architects and planners, who obtained positions at the heart of public debate and governance structures, despite the Nazi occupation of the Netherlands.

Although local interest groups, particularly port entrepreneurs who were specifically interested in town planning and architecture, successfully enforced their visions

51 Brooks, The Family Health Club, II2.

52 The London Gazette, 27 April I956.

53 L. Kuper, «Blueprint for Living Together», in: idem (ed.), Living in Towns. Selected Research Papers in Urban Sociology of the Faculty of Commerce and Social Science University of Birmingham, London I953, I-202, I79.
54 Ibidem.

55 H. Meyer, «Rotterdam: the Promise of a New, Modern Society in a New, Modern City: I940 to the Present», in: J. Ockman (ed.), Out of Ground Zero: Case Studies in Urban Reinvention, Munich 2002 $84-97$. 
on the final reconstruction plan (I946), ultimately, Rotterdam was (re)built by a firmly established apparatus of top-down operating technocrats that took limited notice of public accountability and responsiveness. ${ }^{56}$

In contrast to the blitzed cities in Britain, a social dimension of reconstruction, whether in the guise of public consultation or the inclusion of neighbourhood plans, was largely absent in Rotterdam's reconstruction plan. Community discourse did not emerge publicly in wartime Rotterdam. As the intensity of German occupation gradually amounted to a complete Gleichschaltung of politics and society, access to the arenas of reconstruction politics depended on a highly contingent set of inter-personal relations and surviving local networks that were able to permeate Nazi-controlled governance structures. ${ }^{57}$

Reconstruction politics was strongly predominated by the emphasis on the physical reappearance of Rotterdam's destroyed areas and on the recovery of the port district. The social dimension of reconstruction in Rotterdam, in contrast, remained underground until the liberation from German occupation in May 1945. From then onward, the social aspects of reconstruction politics were heavily debated in public by a group of competing urban intellectuals. ${ }^{58}$ Many of these intellectuals were wealthy port entrepreneurs whose families had already been engaged in public affairs since the late nineteenth century. They surrounded themselves with architects, planners and local officials, with whom they debated their private plans for the city, ranging from social housing and educational programmes to participation in industrial management. ${ }^{59}$

During the last war years and particularly after the war, debates about community planning and social reconstruction were structured around the idea of the neighbourhood unit, the wijkgedachte in Dutch. In general, the debate advanced from the common analysis of social decay and alienation in the metropolis. Solutions were to be sought in the realm of neighbourhood planning, as was promoted by the American sociologist Clarence Perry from the late I920s onwards. Neighbourhood units reflected a (human) scale that would allow the social necessities of the urbanite, and of

56 On the technocratic nature of Dutch (and Rotterdam) reconstruction politics see: C. Wagenaar, «Wederopbouw. Idee en mentaliteit», in: K. Bosma / C. Wagenaar (eds.), Een geruisloze doorbraak: de geschiedenis van architectuur en stedebouw tijdens de bezetting en de wederopbouw van Nederland, Rotterdam I995, 225-23I; K. Bosma, «Het politiekorganisatorisch kader», in: ibid., 23I-24I; C. J. M. Schuyt / E. Taverne, 1950. Welvaart in zwart-wit, The Hague 2000, I63-I68. On the particular history of the Rotterdam Basisplan 1946 see: N. Mens, W.G. Witteveen en Rotterdam, Rotterdam 2007 , I38-I55; A. Tijhuis, «Vergeten stadsbeelden», in: G. Andela / C. Wagenaar (eds.), Een stad voor het leven. Wederopbouw Rotterdam 1940-1965, Rotterdam I995, 2I-58; Wagenaar, Welvaartsstad, 215-
236; L. de Klerk, Particuliere plannen. Denkbeelden en initiatieven van de stedelijke elite inzake de volkswoningbouw en de stedebouw in Rotterdam, 18601950, Rotterdam I998, 236.

57 For a recent summary of this entanglement of ruling elites see: P. van de Laar, «Modernism in European Reconstruction-Policy and Its Public Reception: The Image of Rebuilding Rotterdam, I945-2000», in: Wagner-Kyora (ed.), Wiederaufbau, 212-216.

58 C. Rooijendijk, That City Is Mine!: Urban Ideal Images in Public Debates and City Plans, Amsterdam Q Rotterdam 1945 - 1995, PhD thesis University of Amsterdam 2005, 68-84.

59 De Klerk, Particuliere plannen. 
the nuclear family, to be realised in concordance with the alleged needs of the nuclear family.

The historiography distinguishes between two local groups that gave rise to ideas about neighbourhood and community planning in Rotterdam. The first, most noted group was led by the municipal director of housing, Alexander Bos, and consisted of civil servants, architects and planners who discussed the underpinning social and cultural values of Rotterdam's redevelopment from 1943 onwards. ${ }^{60}$ The second group less prominently discussed in reconstruction literature - was known as the Rotterdamsche Gemeenschap (RG), a voluntary association that was officially founded in September I944 and aspired to foster active citizenship, which would produce community life that transcended existing social and political cleavages in urban society. ${ }^{61}$

Despite adopting the framework of the neighbourhood for community planning, both groups differed fundamentally in the way they wanted to realise the neighbourhood communities. Bos' study group propagated a rather defined set of neighbourhood assets, which were to be carried out by public authorities. The RG took a somewhat different stance: the neighbourhood community had to define and articulate its own needs and interests. ${ }^{62}$ While the study group of Bos promoted an expert vision on neighbourhood planning, the RG, in strong contrast, propagated hands-on action by the citizenry from the very start. ${ }^{63}$

\section{Neighbourhood, Associational Life and Democracy: The Idea of the Rotterdamsche Gemeenschap}

Most neighbourhood unit advocates postulated a certain spatial arrangement of houses and amenities, which would produce a sustainable neighbourhood community. The RG, on the other hand, prioritized grassroots activity and associational life. A sociopolitical reading of the neighbourhood unit underpinned the RG's agenda, as it aspired to establish «a new way of living together». ${ }^{64}$ During its formative phase, from September I944 until mid-I947, the RG represented a very ambitious agenda of civic participation and active citizenship within the association of the neighbourhood. The RG, thus, conceived of neighbourhood planning as a vehicle for principle democratic reform.

A quote from the RG's main initiator, the wealthy port entrepreneur and jurist J. Ph. Backx (I903-I982), illustrates how community-oriented the project was: «recon-

60 In 1946 the Group Bos published the much-quoted book in which the neighbourhood unit was thoroughly elaborated on within the Rotterdam context: A. Bos, De stad der toekomst, de toekomst der stad. Een sociaal-culturele studie over de groeiende stadsgemeenschap, Rotterdam I946.

61 Some references to the Rotterdamsche Gemeenschap can be found in: De Klerk, Particuliere plannen, 249-26o; W. Vanstiphout, Maak een stad. Rotterdam en de architectuur van J. H. van den Broek,
Rotterdam 2005, 2I2-2I3; E. A. G. van den Bent, Proeftuin Rotterdam. Bestuurlijke maakbaarheid tussen 1975 en 2005, PhD thesis Erasmus University Rotterdam 20I0, 8, note 7; T. Idsinga, Architect W. van Tijen 1894-1974: <Ik ben een rationalist, maar er is meer op de wereld..., The Hague I987, I2I-I24.

62 De Klerk, Particuliere plannen, 260.

63 Idsinga, Architect, I24.

64 De Gemeenschap, I3 October I950. 
struction is a question of [creating] a new popular community». ${ }^{65}$ Amongst an elitist group of industrialists and entrepreneurs, who assembled regularly to discuss the city's future in secret during the war, Backx refused to restrict the meetings' agenda to economic recovery. A few years later, when Backx withdrew from the elitist debates about the economic future, he created his own platform with the RG and wrote more specifically about the neighbourhood community: «The Rotterdamsche Gemeenschap wants individual humans to acquaint and to accept their responsibility towards the Community. It aspires to promote the neighbourhood unit [wijkgedachte], to allow a human being, who is lost in the metropolitan whole, to assert himself within a smaller association, without losing contact with the aggregate whole.» ${ }^{66}$ The institutional configuration, which would enable such social reform, comprised a whole new layer in urban governance. In its early correspondence, meetings and publications, the RG laid out an encompassing scheme of political representation and participation that acknowledged the necessity of decentralising urban governance, marking the neighbourhood - not the city as a whole - as the logical environment for urban, participatory democracy and citizenship. ${ }^{67}$

To accomplish this alternative urban polity, the RG combined a number of discourses that stemmed from interwar and wartime thought on socio-political reform. Firstly, the agenda of grassroots participation in public affairs harked back to Backx's interest - and experiments within his own company - in employee participation. Secondly, the RG underlined the trans-political nature of its project: ideological, confessional or partisan groupings were to be excluded from all neighbourhood affairs. This idea linked up with the so-called concept of breakthrough (doorbraak), a wartime, collaborative effort of detained Dutch intellectuals and politicians, aimed at transcending the ideological boundaries in politics, which gained national prominence after the war. Thirdly, the RG took the local particularities of Rotterdam into account. This implied that not only neighbourhood inhabitants were entitled to participate in urban democracy, but also that the historically established strong position of the industrial elite and the local voluntary associations were included in the RG's representative scheme. ${ }^{68}$ The neighbourhood, the milieus of industrial elites as well as the voluntary associations together formed the corporatist cells of the newly conceived urban demos.

The RG's alternative polity commenced at the neighbourhood level. In each of the I8 neighbourhoods that the RG had identified, a board (wijkbestuur) would be elected that was to articulate the particular interests of the neighbourhood. Notably,

65 City Archive Rotterdam (hereafter CAR), Collection De erven de wed. J. van Nelle, inv.nr. 33I7, J. Ph. Backx, «Over den achtergrond van het stadsplan> [On the background of the city plan] (I942); On Backx see: G. Chr. Kok / F. A. Arnbak-d'Aulnis de Bourouill, Rotterdamse juristen uit vijf eeuwen, Hilversum 2009, 3I7-326.
66 N. N., Wat wil de Rotterdamsche Gemeenschap?, I945, 52.

67 CAR, Collection Hudig, inv.nr. I3II, Minutes of the Gezelschap Rotterdam 1943, response by Anton Blom, treasurer of the RC, 20 February 1945.

68 N. N., Wat wil, 8-II and 45. 
neighbourhood interests were conceived of as interests sui generis and different in each particular neighbourhood in Rotterdam. Neighbourhood interests had never before been taken into account in political decision-making the RG argued; no representative or legislative organ (e.g. parliament, the city council) had ever allowed for the representation and articulation of neighbourhood interests. One member of each neighbourhood board, which de facto served as subdivisions of the general board of the RG, would then be delegated to the Assembly of Delegates of the RG (Vergadering van Afgevaardigden). Additionally, representatives of Rotterdam's industrial elite (organised in so-called kringen) and a selected number of voluntary associations would complete the Assembly.

Essentially, the RG tried to replace the pre-war system of local government by establishing the neighbourhood unit as the organising principle. No sustainable rearrangement of urban space and economic recovery could be expected without a sound organisation of the community whose particular needs and wishes were articulated within the setting of the neighbourhood. Therefore, the RG did not only relate to the typical community discourse that revolved around the restoration of social ties and bonds in the urban context, but it also addressed the regeneration of the political community, the demos. It attempted to foster a mode of political citizenship, based on a participatory and a developmental notion of democracy, separate from party politics, by means of a new institutional design. The RG even suggested that the City Council formally the highest political organ in local government - could very well delegate (parts of) its legislative capacities (particularly with regard to public amenities, education, cultural life, sports and community centres) to the new self-governing institutions of Rotterdam, the neighbourhoods. However, as the local government was reinstated with the municipal elections of 1946 and the reconstruction politics became ever more structured in the late I940s, the RG had to downsize its ambitions radically.

\section{The Rise and Demise of Associational Democracy in Practice}

At first glance, the implementation of the RG's scheme made good progress during the mid-I940s. Eighteen neighbourhood boards were installed, whose members were recruited from the growing number of RG members. Membership figures reached nearly 6000 , including mostly middle class people who were active in the voluntary sector. ${ }^{69}$ Concretely, activities within the RG boiled down to myriad meetings of the separate neighbourhood boards and between the joint boards and the general board. ${ }^{70}$ However, as soon as organisational and administrative matters were finally settled, and neighbourhood politics were ready to take off, the project was stymied by municipal interference.

69 CAR, Collection De Rotterdamsche Gemeenschap, no inventory, Annual Report I946-1947, 6 and 28 .
70 CAR, Collection RG, no inventory, Reports of the wijkraden I945-I947. 
The City Council had approved an experimental scheme, which provided for the establishment of representative neighbourhood councils (wijkraden), particularly in the remote residential districts. These councils, of which eleven were installed between I947 and I953, were appointed by the municipality and served as formalised advisory bodies with regard to the provision of amenities in each neighbourhood..$^{71}$ The composition of the neighbourhood councils was entirely based on the proportional representation of political parties.

Evidently, the establishment of wijkraden was a blow to the RG. Firstly, in many neighbourhoods the RG boards had to compete with the municipal councils over a say in public affairs. Secondly, the municipal neighbourhood council scheme negated the trans-political, corporatist aspirations of the RG as it organised neighbourhood politics along partisan lines. Thirdly, instead of the envisaged Assembly of Delegates, composed of neighbourhood and civil society representatives, the City Council was affirmed as the main regulator of community and neighbourhood planning. With hindsight, the RG would later state, «the appointment of the wijkraden is deeply regretted, as the RG [...] had imagined it to develop differently». ${ }^{72}$

The municipal neighbourhood policy urged the RG to reflect upon its role. In June I947, the RG announced its transformation from political reform movement to a promoter of neighbourhood centred social activities. ${ }^{73}$ In its periodical the RG valued this transformation as the result of a «false start».74 The neighbourhood boards (wijkbesturen) were now defined as coordinating bodies that would bring together all sorts of voluntary associations within the neighbourhood. This would foster collaboration and the articulation of common interests, in particular with regard to (new) facilities in the neighbourhood. To streamline this collaboration, neighbourhood boards were divided into functionalist sections, such as youth, culture, sports, education, and socio-medical care, allowing all the relevant ideologically defined voluntary groupings (mainly socialist, catholic and protestant) to cooperate.

As such, the RG shifted from grand socio-political reform to feasible social and cultural activities for and by neighbourhood citizens (e.g. excursion trips, gardening, sports, amateur theatre etc.). However, again, the new set-up was frustrated by municipal interference. In 1949 the municipality installed a Social and Cultural Council as the deliberative platform for the city's voluntary associations. Together with municipal delegates the voluntary sector would deliberate over citizens' needs and wishes with regard to socio-medical care, leisure, religion, social activities and related amenities. Again, this clashed with the RG's ambition to coordinate the entire voluntary sector

71 CAR, Collection General Affairs, inv.nr. 34, Explanatory memorandum about the Neighborhood Councils.

72 CAR, Collection Social Affairs (hereafter SA), inv. nr. 127, Het Contact. De Rotterdamsche Gemeenschap, 26 February I95I.
73 N. N., Verslag van de werkzaamheden van de Stichting <De Rotterdamsche Gemeenschap over de periode 1 September 1946 - 1 Juni 1947, Rotterdam I947.

74 De Gemeenschap, April I948. 
along similar lines at the neighbourhood level, pushing the organisation's activities even more into the direction of simply providing leisure programmes. Consequently, the number of RG boards decreased. In March 1948, only eleven RG board existed, of which three were considered inactive. ${ }^{75}$

Meanwhile, the RG approached municipal authorities to attune both trajectories of community building. In the Commission for the formation of neighbourhoods (Commissie voor de wijkvorming), which convened regularly between September I947 and I949, municipal officials acknowledged the existence of the RG neighbourhood boards but simultaneously stressed the supremacy of the neighbourhood councils. ${ }^{76} \mathrm{~A}$ small victory for the RG was the award of an annual municipal subsidy of 50.000 guilders, to cover its expenses, as it could no longer depend on its voluntary contributions and gifts.

During a lengthy meeting on I9 January I950, a socialist alderman and former secretary of the RG in the early stage, proposed a probationary period to the RG, to see whether the public neighbourhood councils and the private neighbourhood boards could coexist or not. Until then, the municipality would not install new councils. Biannual meetings between councils and boards were introduced too. ${ }^{77}$ During the probation, however, the situation worsened for the RG, which it seemed to recognise, employing a much less confident language: «The work of the RG is still one of searching and sensing, as it is an experiment.» ${ }^{78}$ Its reputation suffered from the increasing stigma of being regarded as moral crusaders. In Katendrecht, for instance, one of the districts in which port workers and seamen dominated much of the public life, the RG neighbourhood board had warned the police about the deterioration of women's moral values. Their letter was leaked to the local press, exposing the writers - two shopkeepers, a pastor and a clergyman (all RG members) - who were subsequently neglected and ostracised by the neighbourhood..$^{79}$

Moreover, in neighbourhoods where municipal councils had been installed, the presence or foundation of an RG board was increasingly deemed unnecessary and unwanted. ${ }^{80}$ The renowned first secretary of the RG in I950, the former municipal housing official and neighbourhood planning advocate, W.F. Geyl experienced many disappointments as he saw the RG losing grip on its aspirations: it had failed to regulate and coordinate social and cultural activities at the neighbourhood level, mostly due to absence of confessional and communist voluntary associations.

Geyl, who had considerable experience with the municipal fabric of community building, became convinced that the municipal policy would do much more for the amelioration of community life than voluntary enterprises, particularly with regard to

75 CAR, SA, inv.nr. I27, Letter secretary RG to board of Social and Cultural Council, 6 March I948.

7 CAR, Collection Secretary, inv.nr. 28, minutes of the Commissie voor de wijkvorming

77 CAR, SA, inv.nr. I27, Report of meeting between alderman Van der Vlerk and RG delegation, I9
January I950; J. Grandia, De arbeider-wethouder Dries van der Vlerk: een leven van dienst aan de gemeenschap, Amsterdam I990, 370.

78 De Gemeenschap, 13 October I950.

79 De Tijd, 4 November I947.

80 Het Vrije Volk, I6 March I95I. 
the provision of feasible amenities such as neighbourhood centres. One of the naive ambitions - in his eyes - of the RG was the aim to transcend ideological divisions within Dutch society. To him, this pillarization had to be accepted as an immanent feature of Dutch community life. Boundaries between Socialists, Protestants and Catholics, had deep-rooted historical origins, he believed. In the end, the RG was «an ambiguous absurdity», an «anaemic wench», which was only viable because of the financial support of the municipality. ${ }^{81}$

In January I95I, Geyl resigned as RG secretary, leaving the board in dispute. ${ }^{82}$ As in I947, the RG decided to reorganise itself again in 1952. The neighbourhood boards were replaced by loosely organised contact commissions, which would serve as platforms for associational collaboration. ${ }^{83}$ In essence, this reorganisation was a final surrender to the municipal neighbourhood councils. Even by the end of 1953, the RG claimed that its work was «only in the first stage of trial and error». ${ }^{84}$

Continuous conflicts alienated the neighbourhood branches from the central board. Geyl's successor, the well-respected reform socialist J.M. de Heer, had to resign as secretary in March I954. He had secretly reported internal RG affairs to the local reform socialist party. ${ }^{85}$ Furthermore, another voluntary party manifested itself in Rotterdam's neighbourhoods from the early I950s onward. Subsidised community work bodies (wijkopbouworganen) took up the gauntlet of social work, giving rise to yet another force that would prevent the RG from growing to full stature. And as the RG was unable to convince neighbourhood initiatives to associate with them, many new neighbourhoods that were built south of the river Maas in the I950s established their own associations to coordinate socio-cultural neighbourhood affairs. ${ }^{86}$

A few neighbourhood divisions of the RG were able to extend their work until the summer of 1955 when the RG was formally discontinued. Urged by some neighbourhood branches, the RG accepted its dismantling in early I955. The local socialist newspaper wrote: «The Rotterdamse Gemeenschap has been buried without show.» ${ }^{87}$ Its remaining activities (vacation programmes and some social neighbourhood activities) were transferred to other voluntary associations at the neighbourhood level.

\section{Conclusion}

The experimental interlude of the I940s catalysed and sharpened pending ideas and ideals with regard to the reconstruction of urban society. In Coventry, the London based interwar experiments with «positive health» were extended to an integral community scheme including housing, amenities, organic farming, nutrition, health care

81 Het Vrije Volk, I2 March I954.

82 De Klerk, Particuliere plannen, 253.

83 Het Vrije Volk, 27 October 1952.

84 De Gemeenschap, November I953.

85 Het Vrije Volk, 4 March I954; De Maasbode, 5 March I954.
86 CAR, Collection Poor/Social Council, inv.nr. 46, overview of community work and voluntary associations in Rotterdam founded in the I950s, arranged by neighbourhood.

87 Het Vrije Volk, 2 September I955. 
and democratic governance through direct participation in public affairs. In Rotterdam, the experimental interlude gained momentum as soon as the Nazi occupiers were removed from public office. Here, pre-war precedents of planning by voluntary groupings nurtured an alternative conception of urban governance based on neighbourhood organisations. Both projects aimed at, whether explicitly or implicitly, transcending the social and political cleavages and divisions of pre-war society.

The transitional period of the mid-I94os thus witnessed the manifestation of experiments in community planning that emerged from civil society. Particularly in blitzed cities, the need for housing, food and amenities fostered a series of private initiatives that promoted highly idiosyncratic visions of the planning and formation of the urban community. The experiments of the FHC in Coventry and the RG in Rotterdam embodied a belief in planning that denounced the hegemony of public authorities and championed some form of self-government. Moreover, they distinguished and distanced themselves from urban planning by public authorities.

However, as the experimental interlude yielded to the age of centralist planning, and to an increasingly coordinated regulation of society, including the voluntary sector, the rationalities of social reform inscribed into both projects lost ground and support. In the late I940s and I950s public authorities almost exclusively determined the planning agenda, pushing the struggling planning experiments stemming from private initiative to the margins of reconstruction politics.

\section{Experimental Planning after the Blitz. Non-governmental Planning Initiatives and Post-war Reconstruction in Coventry and Rotterdam,}

This article probes into two non-governmental planning initiatives in the bombed cities of Coventry and Rotterdam. It articulates planning practices by non-state actors at the local level during the 1940 s and early 1950 s. These practices comprise a set of alternative visions graafof urban reconstruction and the regeneration of the urban community. Most of these social planning experiments were thwarted by the authorised planning schemes of public authorities from the early 1950 s onwards. However, and engaging with recent historiography on postwar urban planning, these non-governmental experiments disclose that urban reconstruction and planning after aerial warfare in the Second World War was no uncontested or monopolised top-down endeavour initiated exclusively by public authorities and professional planners in the 1940 s.

Stefan Couperus University of Groningen Department of European Languages and Cultures Oude Kijk in 't Jatstraat 26 NL-9712 EK Groningen, the Netherlands e-mail:s.couperus@rug.nl 


\section{Raluca Mușat}

\section{Lessons For Modern Living: Planned Rural Communities in Interwar Romania, Turkey and Italy}

A defining feature of the period between the two World Wars was the desire to modernise the rural world. ${ }^{1}$ In the international arena, private charitable foundations such as Rockefeller and Carnegie and the inter-governmental League of Nations sought to address the problems of the countryside on a global scale, circumscribing the rural as a site of political intervention characterised by specific problems and needs. ${ }^{2}$ On a national level, the countryside became a prominent arena where processes of nation-state building and consolidation took place. The interest in the peasantry was especially high in countries with large numbers of rural dwellers, from France to the Scandinavian countries to Southern and Eastern European states. The combination of modernisation in the guise of «development», and national state-building ideology, formed a unique vision of modernity specific to the interwar period. This article examines three instances of rural planning in three countries. They allow us to see whether or not common traits of this underlying vision of rural modernity existed beyond their respective political, social and economic differences.

Well-known examples of an interwar interest in transforming both the rural environment and the lives of its inhabitants include Mussolini's new towns in Italy, the Tennessee Valley Authority projects in the southern United States, and various model villages built across Eastern and Northern Europe. ${ }^{3}$ Less known are the model villages

1 Some of the more recent discussions on this are: J. Burchardt, «Editorial: Rurality, Modernity and National Identity between the Wars», in: Rural History 2I (20IO) 2, I43-I50; A. Ballantyne / G. Ince, «Rural and Urban Millieux» in: A. Ballantyne (ed.), Rural and Urban: Architecture between Two Cultures, Abingdon. 2010, I-28; J. Scott / N. Bhatt (eds.), Agrarian Studies. Synthetic Work at the Cutting Edge, New Haven, CT, London. 200I.

2 This aspect has been mainly discussed in the field of public health. I. Borowy, Coming to Terms with World Health, Frankfurt a. M.. 2009; L. Murard, «Designs within Disorder: International Confer- ences on Rural Health Care and the Art of the Local, I93I-I939", in: S. Gross Solomon et al. (eds.), Shifting Boundaries of Public Health. Europe in the Twentieth Century, Rochester, New York 2008, I4I-I74; P. Weindling, «Public Health and Political Stabilisation: The Rockefeller Foundation in Central and Eastern Europe between the Two World Wars», in: Minerva 3I (I993) 3, 253-267.

3 There is now a significant literature on such schemes both in the field of history and in the history of architecture. R. Kargon / A. Molella, Invented Edens: Techno-Cities of the Twentieth Century, Cambridge, MA 2008; F. Caprotti, Mussolini's Cities: In- 
built in Romania and Turkey, though they exemplify a similar trend. One such case is Dioști, a small village in South-western Romania. Dioṣti was reconstructed as a model village after a fire in 1938 , under the auspices of the authoritarian King Carol II. ${ }^{4}$ The design principles stemmed from specialists in sociology and architecture. The Turkish model villages built during the ambitious social modernisation process of Mustafa Kemal, known as Atatürk, have received some attention from scholars working on the history of Turkish modernism and its political significance. ${ }^{5}$ Nevertheless, because of Turkey's geographic position, kemalist model villages have rarely been discussed as part of wider European trends of rural planning. ${ }^{6}$ In this article, theyprovide a useful comparison that sheds more light on the case of Dioști. Whilst Diosti remained an exemplary case of a model village, and the only one that was fully realised in Romania, the Kemalist regime managed to complete a significant number of model villages by the mid-I930s. ${ }^{7}$ The best known of the three case studies are the Italian New Towns. Italian fascist architecture was trendsetting, offering inspiration to other countries across the world. In the I930s, small new towns were built across Italy as part of Mussolini's rural politics. The most famous ones were the towns built near Rome on reclaimed marshland, an area that became known as the Agro Pontino. ${ }^{8}$ These three examples were not unique, and seem to represented a common trend present in other European countries. Drawing comparisons between them sheds new light on some of the key features of this trend. In doing so, the main focus is on the Romanian case of Diosti, while the Turkish and Italian cases are used to understand the Romanian one better. ${ }^{9}$ This article thus offers a comparison that is asymmetrical, as it first zooms in on the Romanian model village Dioṣti. Dioști's transformation is analysed in more detail, and the Italian case is used as a point of reference from which to look at the other schemes. ${ }^{10}$ This comparison serves to shed more light on the wider implications of rural planning in the interwar period.

In these schemes, planning involved not only the execution of construction work, but also the resettlement of people to various territories, the transformation of nature and the remodelling of people's lifestyles. These examples of rural planning can therefore be seen as episodes in the expansion of the «social» realm into the rural world. In

ternal Colonialism in Italy, 1930-1939, New York 2007; D. Ghirardo, Building New Communities. New Deal America and Fascist Italy, Princeton, NJ I989.

4 For a more detailed discussion of this project see R. Mușat, «Prototypes for Modern Living: Planning, Sociology and the Model Village in Interwar Romania», in: Social History 40 (20I5) 2.

5 The main sources available in English on this topic are: S. Bozdogan, Modernism and Nation Building: Turkish Architectural Culture in the Early Republic, Seattle, WA 2002; S. Bozdogan / E. Akcan, Turkey, Modern Architectures in History, London 2012.
6 A. Cengizkan / D. Kilickiran, «From the «Model Village to a Satellite Town», in: A. Ballantyne (ed.), Rural and Urban: Architecture between Two Cultures. Abingdon, New York 2010, I90-207.

7 By I933 there were 69 new villages. Bozdogan / Akcan, Turkey, 36.

8 On the Italian new rural towns see: Caprotti, Mussolini's Cities, Ghirardo, Building; Kargon / Molella, Invented Edens.

9 R. Mușat, «Prototypes».

10 J. Kocka, «Comparison and Beyond», History and Theory 42 (2003) I, 39-44. 
the view of scholars like James C. Scott and Paul Rabinow, the birth of modern forms and practices of governance meant that states became solely responsible for the transformation and eventual perfection of their societies. This led to the creation of a sphere of concern about the life and wellbeing of the population, generally defined as «the social». In his analysis of French modernity, Rabinow described the interplay between «the construction of norms and the search for forms adequate to understand and to regulate what came to be known as modern society». ${ }^{11}$ If the norms corresponded to ideas about planning social transformation, the forms corresponded to the disciplines and technologies that gave real shape to these ideas. Over time, the sphere of the social expanded from the interest in the wellbeing of the elites to the working classes and eventually to the entire population.

The interwar period represented a key moment in the consolidation of a vision of modernity in which the rural world became an integral part of the social realm. My argument is that in each case, these new planned communities represented models or metonyms for the transformation of the entire society, understood as an expansion of the state into its rural hinterlands.

There are important similarities between the social, economic and political circumstances that drove the desire to transform the rural world in the cases compared. First, all three countries had significant peasant populations that had little formal relationships with the the state, living in what came to be seen as backward yet traditional conditions. In Italy peasants made up half of the population, whereas in Romania and Turkey they even formed a much larger majority (more than 70 per cent). In all three countries, these rural populations played an integral part of the process of national modernisation. Nevertheless, demographics would not have counted for much had it not been for the active political need to transform peasants into masses of consenting subjects. ${ }^{12}$ Second, all these initiatives represented the new cultural values of the regimes that invented them: Italian Fascism, secular Kemalism and the soft authoritarianism of King Carol II. In this sense, we could circumscribe these planning initiatives to wider «civilising missions» through which masses were to be educated and socialised into modern yet highly politicised ways of living. ${ }^{13}$ Last but not least, the third important prerequisite that made these schemes possible was the presence and role of experts. Architects, sociologists, demographers, and urban planners played leading roles in providing the tools and practices for this social engineering. ${ }^{14}$ They were not only mediators between the state and the old or new inhabitants of these model settlements, but also carriers of ideas that provided the link between the international and

11 P. Rabinow, French Modern: Norms and Forms of the Social Environment, Chicago I995, 9.

12 V. DeGrazia, The Politics of Leisure: The Dopolavoro and the Organization of Workers' Spare Time in Fascist Italy, 1922-1939, Cambridge I98I.

13 N. Elias, The Civilising Process, Oxford I978.
14 On how rural architecture has reflected different anxieties and problems of the modern world, see Ballantyne / Ince, «Rural and Urban». On interwar architecture in these countries, see D. Ghirardo, Italy, Modern Architectures in History, London 20I2; C. Popescu, Le style national roumain. Con- 
the national arenas. Architects and social scientists from Italy, Romania and Turkey were parts of international networks of knowledge that shared a common vocabulary and common categories about rural hygiene, housing and development. Architects and social scientists were connected to international discourses, sustained by conferences, fairs, and journals. They thus were aware of common issues and of the different solutions specialists from other countries had adopted for the countryside. Planning in rural areas therefore represented a terrain where, when given the opportunity, specialists could experiment with these ideas.

The remaining part of this article looks at these three cases in more detail, indicating the specific problems these projects were meant to address, as well as the ideas and expectations they shared.

\section{Dioști, a Pilot of Rural Modernisation}

A new enlarged Romanian state emerged out of the diplomatic negotiations following the end of the First World War. ${ }^{15}$ Despite the fact that its population and territory almost doubled and its ethnic mix was greatly increased, the new state remained overwhelmingly agrarian. Whilst this social make-up posed specific problems to smaller pre-war Romanian kingdom and to the imperial governments reigning over the other territories that became part of greater Romania, the unification transformed the terms of the «agrarian question» entirely. Firstly, the «Romanian» countryside became even more diverse than before, incorporating rural dwellers that had lived under different political regimes and systems of land tenure. Secondly, the promises of the early postunification period called for a redefinition of the place the peasantry was to occupy both in economic and political terms. The I92I land reform redistributed land to the majority of the peasant population and, despite its many flaws, did away with the largescale agricultural (neo-serfdom) mode of production prevalent in the Old Kingdom. ${ }^{16}$ The new vision for agriculture involved creating a new class of independent small-scale agricultural producers who would supply an internal market as well as become consumers of urban goods. This informed much of the political and economic debate of the period. Thirdly, in the international post war context and the unification led to a shake-up of Romanian politics. The old system of rotation that included the two main parties, Liberal and Conservative, collapsed, bringing along the total demise of the latter party that represented the class of landowners. The I923 Constitution ex-

struire une nation à travers l'architecture 1881-1945 Rennes, Bucharest 2004; Bozdogan / Akcan, Turkey; C. Popescu, «Modernitate în context», in: idem, (Dis)continuităti Fagmente de modernitate românească în prima jumătate a secolului al 2o-lea, Bucharest 20IO, II-IOO.

15 H. L. Roberts, Rumania: Political Problems of an Agrarian State, New Haven, CT, London. I95I; K. Hitchins, Rumania: 1866-1947, Oxford I994.
16 D. Mitrany, The Land and the Peasant in Rumania: The War and Agrarian Reform (1917-21), New Haven, CT, London I930; D. Mitrany, «The New Rumanian Constitution», in: Journal of Comparative Legislation and International Law 6 (I924) I, IIO-II9. 
tended the vote to the entire peasant male population, inviting them to participate in Romanian politics. New political parties sprung up, promising to represent, alongside other voters, the rural masses. Overall, these top-down transformations - territorial and legal - integrated the Romanian countryside, at least nominally, to the previously much smaller social, political and cultural spheres.

Whilst the actual integration of the peasant masses into the social and political spheres of the state occurred slower than the pace of legal reforms suggested, the work of Romanian scholars and social reformers transformed the rural world into a space of scientific and social experimentation. ${ }^{17}$ In the I920s and I930s, specialists from a wide range of academic fields such as sociology, psychology, social medicine and urban planning translated well-known problems of rural life into the vocabulary of their respective disciplines, drawing attention to issues such as malnutrition, infant mortality and different «social diseases» (tuberculosis, typhus, malaria, pellagra, syphilis) that plagued Romanian villages. ${ }^{18}$ In coining a new scientific understanding of the countryside, the main question specialists as well as politicians were faced with was how to modernise the countryside while preserving the traditions of rural living and make peasants economic and political agents.

A vision of planning rural areas grew out of a series of related issues that gained importance for rural specialists after the war $1918 .{ }^{19}$ The first of these was the problem of rural housing. As architects, doctors and social scientists who undertook research in the countryside discovered, a great number of Romanian villagers lived in wretched conditions, sleeping in close proximity or even with their animals under the same roof, living in hovels or sharing the same bed with several other members of their family. Another facet of the housing issue was related to the population exchanges in the region that led to the construction of several new villages or sections of villages in different parts of the country, especially Dobrogea. ${ }^{20}$ The concern with rural housing played an important part in the development of a new sub-discipline of urban planning, that of rural planning (known in Romanian as ruralism). Although clearly less prominent,

17 M. Bucur, Eugenics and Modernization in Interwar Romania, Pittsburgh 2002; M. Turda, Eugenism și antropologie rasială în România, 1878-1944, Bucharest 2008; R. Musat, «Sociologists and the Transformation of the Peasantry in Romania I925I940», Unpublished PhD thesis, London 20II.

18 For an overview of these problems at the end of the interwar era see D. Gusti / N. Cornatzeanu / G. Banu, Rural Life in Rumania. An Abridged English Version of a Monograph «La Vie Rurale En Roumanie», Bucharest I940; and G. Banu (ed.), «Problemele sanitare ale populatiei rurale din România», in: Revista de igienă socială X (I940), I-6. For an account of Romanian peasant problems in a wider context, see D. Warriner, Economics of Peasant Farming, London, New York. I939.
19 N. Lascu, «L'espace rural et l'architecture moderne durant les entre deux guerres», in: Genius loci: national et regional en architecture entre histoire et pratique, Bucharest 2002, I68-I73.

20 F. Stănculescu, «Satele noui formate în legătură cu reforma agrară», in: Arhitectura IV (I925),: 28-29. On the details of the internal colonisation phases, see E. Grințescu, Colonizarea: principii și realizări, Bucharest. I944 and V. Solonari, Purifying the Nation Population Exchange and Ethnic Cleansing in Nazi Allied Romania, Baltimore, /MD. 2009. 
this discipline developed in the I920s and I930s around several architects and publications of the period. ${ }^{21}$

Another area that influenced the development of rural planning was the concern with the health, hygiene and wellbeing of people living in the countryside. ${ }^{22}$ These concerns were voiced by specialists of social medicine and social hygiene, domains that were blossoming in Romania, as in many other parts of the world. Thus, housing conditions became tightly linked with the need to «heal the rural world» by teaching peasants how to wash, eat healthier diets, trust modern medicine, etc.

The idea of creating «model villages» where locals would be encouraged to become models for their own neighbours or for people like them across the country grew out of these different specialised discourses, which resonated with the wider international scene. Until the late I930s, the model village and rural planning more widely remained at the stage of proposals, plans and debates rather than actual physical projects.

A third interrelated context that gave more strength to the idea of educating peasants through exemplary projects came from the discipline of sociology. The project of cultural work, initiated by Gusti, the director of Royal Cultural Foundations and leader of the Bucharest School of Sociology, brought young specialists from different disciplines to the countryside in order to use their knowledge and skills to transform rural living conditions. ${ }^{23}$ The project used competitions amongst villages as an educational method, designating model institutions or model villages to stimulate locals to improve their habitat and lifestyle while preserving their local customs and traditions. ${ }^{24}$

All these different concerns found their realisation in the small-scale reconstruction of Dioști, a village in the South-West of Romania that had burnt down and was rebuilt as a model village. This project was the result of a set of coincidences.

At the beginning of 1938 , King Carol II announced his personal dictatorship. Carol had initially renounced the throne in 1925 , but reclaimed it in 1930 when he returned to Romania with the support of an important part of the political and intellectual elite. From then on, his rule was characterised by high-level corruption and fraud, intrigues and a continuous effort to undermine the power of the existing political parties. In 1937, the King took advantage of the circumstances created by elections when the Legion of the Archangel Michael, the home-grown fascist organisation, got sixteen per cent of the votes, appointing the leader of a less prominent extremist organisation to form a government. After a short term in office, famous for its anti-Semitic brutality, Goga was dismissed and the King took a firm hold on power, declaring his personal

21 F. Stănculescu, Contributii la afirmarea arhitecturiii românești, Bucharest I9 87 ; N. Lascu, «L'espace rural», I68-I73.

22 Banu, «Problemele sanitare»; Bucur, Eugenics.

23 Z. Rostás, Monografia ca utopie. Interviuri cu Henri H. Stahl (1985-1987), Bucharest 2000; Z. Rostás, «Fundația Culturală Regală <Principele Carol〉 sau miṣcarea echipelor studențești voluntare», in:
Z. Rostás, Strada Latină 8. Monografisti si echipieri la Fundatia Culturală Regală «Principele Carol», Bucharest 2009, II-23.

24 For an overview of this project see R. Muṣat, « Cure, Uplift and Ennoble the Village: Militant Sociology in the Romanian Countryside, I934I938», in: East-European Politics and Societies 27 (2013) 3, 353-375. 
dictatorship at the beginning of 1938. Unlike Mussolini's Fascism or Kemalism, King Carol's regime lacked a coherent ideological stance. The regime was, like the king himself, weak but ornate, heavy in propaganda and light on any real results. In its propaganda, the new regime was to end the petty struggle for power amongst various political parties and to bring a new fairer and more stable rule over the country. As part of his political agenda, the King was interested in creating a new alliance with the peasantry, who had become the target of the Legion. ${ }^{25}$ Thus, after the instauration of the royal dictatorship, King Carol showed an increased interest in the reform the countryside. What better chance to show his royal mercy towards the rural masses than a natural catastrophe? That spring, droughts caused many villages to go up in flames, including Dioști, the place that was to be transformed into a model village.

The main project of rebuilding Dioști as a model village lasted only two years. ${ }^{26}$ During this short time, the structure of the locality was redesigned according to modern principles of architecture, planning and sociology. The new section that was added to the existing part of the locality, which had not been damaged by the fire, consisted in a civic centre, a new road with model houses and several other public buildings. The architects used a stylised vernacular of the area for the private houses, which had many outbuildings and a rational, yet simple organisation of the interiors. The new public buildings, including the central Village Hall, combined simple functional structures with vernacular decorative motifs. Besides, the village was equipped with a stadium, a water pump and an electric plant.

Beyond the modern design, scientific knowledge and generous funds, the success of the rebuilding of Dioști required a minimum cooperation from the local community. Since it was in fact a major relief project, the representatives of the village elite met the initial proposals with great approval. This was understandable, given that they had lobbied for their village to become a model in the first place. ${ }^{27}$ However, some resistance appeared when the plan started to be implemented in practice. Unlike other rural development projects that were built on «virgin land», this project involved some seizure or redistribution of land. This was the point at which some locals reverted to a customary distrust of all forms of external authority, refusing or seeking to resist the seizure of their plots even if they were being promised a new house complete with an adjacent plot of its own. Despite the planners' hope to use this as a means of building new social ties between the state, voluntary workers and the local community, the villagers participated to different degrees in the construction of their own new model home. Some people overcame their distrust and cooperated in the building of the model houses. Others, especially those who had not been directly affected by the fire, remained indif-

25 For works on Romanian Fascism and its rural projects see A. Heinen, Legiunea «Arhanghelul Mihai», Bucharest 2006; R. Haynes, «Work Camps, Commerce, and the Education of the «New Man» in the Romanian Legionary Movement», in: Historical Journal 5I (2008) 4, 943-967. 26 G. Focșa, Satul model Dioṣti, Bucharest I94I, 26-27. 27 A. Ciobanu, Monografia comunei Dioṣti, I973. 
ferent to the rebuilding of the village and proved unwilling to change the way they worked their own land. These shortcomings showed the limits of this elite, state-driven initiative with two contradictory aims: a fast, radical and therefore superficial transformation of the locality and the inculcation of a spirit of self-help and cooperation amongst the local community.

The reconstruction of Dioști as a model village, in which sociologists, architects, rural planners, the monarchy and the locals played a part, was designed as a pilot for a future large-scale project of rural modernisation. The project was realised as a concrete example of the monarch's new vision of the countryside, being a prototype for similar projects to follow. ${ }^{28}$ Its overall aim was to transform this community both aesthetically and socially by combining the best from the traditional heritage of the area with the improvements of modern living.

The outbreak of the Second World War and the abdication of King Carol II meant that the project in Diosti was stalled and left unfinished for several decades. However, the plans for more similar model communities, some of which were started during general Antonescu's regime (I940-I946) show that this type of exemplary rural development persisted until the communist take-over of $1948 .{ }^{29}$ After the take-over, for the following two decades, the communist regime proposed a very different type of rural transformation that focused on the collectivisation of agriculture and on industrialisation. New plans for the systematisation of the Romanian countryside resurfaced on the political agenda of the Ceausescu regime, only in the I970s, when interwar ideas about rural planning were reinterpreted in a new light. ${ }^{30}$

\section{Kemalist Model Villages}

At the end of the First World War, the new Turkish state emerged from the ashes of a great but long-convalescing empire and, like Romania, it also embarked on a process of great social and political modernisation. The foundations were set during the authoritarian regime of Atatürk who believed that the key to his country's future was that of «modern civilisation». The reforms introduced in the mid-I92os and especially in the I930s redefined what it meant to be a Turk living in the new Turkish nation. Starting with the mid-I920s the old Ottoman establishment was dismantled piece by piece. The new secular republic had a civil code based on the Swiss model, a criminal code based on Mussolini's and a new Latin alphabet. Both men and women received the right to vote, although the regime was by no means democratic. ${ }^{31}$ In the social and cultural spheres, the modern ethos expanded from the urban centres where the educated elites were based outwards into the countryside to enlighten and civilise the peasant masses. 
The modernising reforms of the I930s required the mobilisation of the country's intellectual elites who were given the task of translating them into actual «norms and forms». As elsewhere in Europe, social scientists and architects became the mediators between the state and the social masses, especially rural ones, working to put the new ideas into practice.

Architecture played an important role in creating the visual identity of the new regime in Turkey. Inspired by their counterparts in Italy and Germany, Turkish architects adhered to the modern movement present in many other countries across the world at the time, drawing their inspiration from Le Corbusier, Italian fascist architecture and the earlier Garden City movement. Apart from working on urban areas, these experts of modern living became actively involved in the transformation of the countryside. The architect Adibin Mortas made this clear by noting that «villages are of paramount significance in the nation building and must be designed by the professional architect». ${ }^{32}$ The quote highlights the desire of professional architect to expand their expertise into the rural space, claiming their place in their country's state modernisation.

The model villages built in this period were examples of the practical implementation of Kemalist reforms. The first impetus for these projects was the housing need generated by the population exchanges resulting from the First World War settlements. The redrawing of European states' borders at the end of the First World War resulted in a major displacement of populations. For Turkey, this problem was compounded by the conflict with Greece that generated an important series of population exchanges between the Balkan states in the region that in turn called for the building of new settlements. ${ }^{33}$ However, model villages soon came to represent more than just a response to a demographic issue. Instead, they became part of a wider programme of rural modernisation meant to transform the Turkish peasantry and the countryside as a whole (köycülük). As Bozdogan noted, this «was an ideological, cultural and educational mission to be taken to the remotest, harshest, and most inaccessible corners of the country with revolutionary zeal, idealism and sacrifice».34

As in the rest of the Balkans, the vast majority of the Turkish population lived in rural areas often in poor conditions and forming a specifically peasant culture. As their perceived backwardness represented the backwardness of the country as a whole, the enlightenment of the peasantry and their transformation into loyal citizens of the state became a priority for the new governments. Turkish leaders and rural specialists drew inspiration from the wide variety of projects and programmes employed to transform rural populations elsewhere. For example, their initiative to build People's Houses as community centres for popular education were influenced by the Italian case del fascio, whereas the principles of planning model villages were also often inspired by Musso-

32 Bozdogan, Modernism, Ioo.

33 R. Hirschon (ed.), Crossing the Aegean: An Appraisal of the 1923 Compulsory Population Exchange

Between Greece and Turkey, Oxford, New York 2003 .

34 Bozdogan, Modernism, I03. 
lini's New Towns. ${ }^{35}$ At the same time, the importance of the People's Houses initiative paralleled the Romanian initiative of building cultural centres in the villages supported by the Prince and then King Carol II. Planning in rural areas was therefore part of a widespread desire to educate and enlighten the countryside according to rational principles of modern hygiene, health and civic conduct.

In terms of planning, the new model villages reflected the diversity of the Turkish architectural scene itself both in terms of ideas and of stylistic realisation. Some model villages, for example, were built in a very modern style, devoid of all ornamentation, whereas other revived and integrated elements from the vernacular styles of the region into their new designs. The «ideal republican village» designed by Kazım Dirlik faithfully reproduced the concentric zones of Ebenezer Howard's garden city plan. Another architect, Aptullah Ziya, proposed a more conservative take on the model village. This involved a square plan with a central square for the main local institutions and public places. Furthermore, his proposal that traditional materials be used in the making of the houses indicated a vision of the rural future emerging and growing naturally out of its own past. ${ }^{36}$

Planned rural communities in Kemalist Turkey reflected all the tenets of the regime: republicanism, nationalism, revolution, secularism, populism and statism. This indicates both the similarities with and the differences from the Romanian and Italian cases. Unlike Dioști, the Kemalist villages represented radically new political and cultural values (secularism being the most important) that reflected the revolutionary essence of the regime. Instead, the drive to change rural life in Romania was a truly reformist one that sought to maintain the existing status quo intact as much as possible. In both the Romanian and Italian cases, religion was to be preserved as an important part of village life. On the other hand, these projects were similar in their drive to integrate the rural into the sphere of the state and into an idea of modern society with coherent cultural values and codes of conduct. This was realised through the research and work of experts - architects and social scientists - who in turn welcomed the opportunity of contributing to the improvement of rural living conditions and aesthetics. Thus, the political dimension indicates that radical political change combined with the power of authoritarianism made planning in rural areas a much more powerful tool than in Romania. The common element underlying these cases was that the development of planning as a set of combined disciplines harnessed the power of the state, allowing planning to expand into the countryside as part of a civilising mission. 


\section{Mussolini's New Towns}

In the case of Italy, the rural population posed a different set of problems than in the Balkans. Regionally, Italy was a country of great contrasts, with a rapidly industrialising North and a highly agricultural South, where the rural population was still working in wretched conditions for powerful landowners. In terms of overall numbers, almost half of the Italian population lived in rural areas and, although the fascist regime greatly supported industrialisation, agriculture remained one of the most important sectors of the Italian economy. ${ }^{37}$

In legal terms, the end of the war and the advent of the fascist regime did not radically alter the status of the peasantry as had happened in Eastern Europe (Romania included) where massive land reforms led to important redistributions of property. Instead, the fascist rural politics were aimed rather at building consensus and support in the countryside and at preventing the migration of peasants from the country to the cities. ${ }^{38}$

Similar the other cases discussed above, the five new towns built in the Pontine Marshes area were a response to several interconnected social and political issues. They were part of efforts to govern the rural at a time of economic and political crisis, represented by the politics of internal colonisation and restrictions on internal migration. They were also tools of political propaganda for Mussolini and for fascism, representing the triumph of the regime over nature. ${ }^{39}$ As the propaganda showed, the technology employed by the state was next to miraculous, creating fertile land out of malaria-ridden marshes. This indicates the similarities to the Romanian case of Dioști, where nature was also used as a contrast to the rational force of modern rational planning and of the royal mercy of another powerful leader, King Carol II. However, whilst the model village of Diosti was meant to preserve rural society more or less in a same form as before, Mussolini's new towns represented a step further: creating an urban settlement that had the social and moral order of the rural world. This desire of preserving the best of the two worlds, urban and rural, was by no means new, evoking the dream of the English garden city planners. ${ }^{40}$

The architectural design of the Italian new towns used the best of architectural innovation and skills present in the country at the time. The towns were built according to plans that had been selected after a public competition and reflected the aesthetics of the fascist regime. As in the other two cases, there was not a unique style in which all new towns were built, but rather different variations that ranged from a rational style to a modernist one that included vernacular influences. For example, the new town of Torreviscosa in Northern Italy included local Friulian influences, whereas Sabaudia,

37 F. Caprotti, «Destructive Creation: Fascist Urban Planning, Architecture and the New Towns in the Pontine Marshes», in: Journal of Historical Geography 33 (2007), 65I-679.

38 P. Wilson, Peasant Women and Politics in Fascist
Italy: The Massaie Rurali, London 2002; DeGrazia, Politics of Leisure.

39 Caprotti, «Internal Colonization».

40 Ghirardo, Building New Communities; Ghirardo, Italy. 
one of the Pontine towns was planned by Luigi Picinato, who «drew much of his inspiration from Frank Lloyd Wright's Broadacre city». ${ }^{41}$ This shows how wide the vocabulary in which interwar architecture expressed visions of rural modernity was. It would be wrong to say that fascist Italy had reached a definite idea about the future of the countryside. Instead, we should take these small-scale projects as samples or prototypes that reflected different solutions for this future.

Overall, the Italian new towns employed and displayed all the techniques of urban planning adapted to the different conditions of the rural. In designing the space of these new communities, planners preserved some elements of traditional villages, adding or altering aspects regarding public life. These new towns, like the model villages in Turkey and Romania, always displayed the presence of the state at the heart of rural life. This was a clear statement about the expansion of the public or social sphere into the private and in once isolated rural areas. In the Italian case, the regime was represented visually through bold architectural statements such as the church in Sabaudia (The Chiesa dell'Annunciazione). ${ }^{42}$ The civic centre, casa del fascio, a new addition that could be found to most new towns and even villages of this era, also represented the connection between the rural world and the state.

The relation between the state organisations and the colonists does however indicate that the planning of these new lands represented a negotiation rather than a oneway process. The recruitment of colonists proved harder than initially predicted and standards had to be dropped. The regime therefore ended up bringing people who did not represent «model citizens», but often people who had nothing to lose in the areas where they were currently living. Since most of them were not agricultural workers, they often preferred having money to dedicating themselves to the land. This often led to resistance to and negotiations with the main institution in charge of the project over the amount of money they were allocated.

\section{Planning the Rural in the Interwar Period: the Comparative Dimension}

The planned communities discussed in this article were by no means isolated and unrelated. Despite rather different political regimes, cultural spaces and economic modes of production, these instances of rural planning belonged to a common desire to build modernity in the countryside. Read closely, this desire showed various peculiarities from case to case.

The first point of difference was political. Despite all being non-democratic regimes, Fascism, Kemalism and Carol II's personal dictatorship represented different ideological stances and, to some extent, different modernisation impulses. These were reflected in the rural projects built by these regimes. In all three cases the village repre-

41 Kargon / Molella, Invented Edens, 52.

42 Caprotti, Mussolini's Cities, 673. 
sented both a «locus of the nation and of modernity», although the moral and social order proposed often differed. The desire to secularise, specific to Turkey, differed from the subordination of the church to the power of the state in Romania and Italy. The differences between these visions extend even further. In Turkey and Romania, despite the new designs of the houses, of roads and public buildings, the model villages sought to keep peasants on the land living rural lives. Instead, the Italian case was more ambitious. In a similar vein to the earlier Garden City movement, the Italian planners and architects imagined a new form of living that combined the best of urban and rural. Their new towns emphasised rural social values despite being essentially urban spaces. However, at the same time, the high degree of invention and innovation was counterbalanced by the desire to preserve and to maintain the status quo and thus to create political consent in the countryside. ${ }^{43}$

Other differences were present in the relation between the state and the inhabitants of these new communities. Unlike most of the Turkish and Italian cases, Dioști was built for the locals rather than for colonists. This involved a different negotiation with the existing community than in the two other countries. In Romania, the planners had less leverage over the locals since the people owned their own land. This was different from Italy, where colonists were recruited from elsewhere and where the negotiations with the new inhabitants lasted several years. In Turkey, where colonists were the result of resettlements, people were under greater pressure of accepting the new homes since in most cases they had nowhere else to go.

This leads to another related point of difference: the scale of these projects. Whilst the Romanian one was a very small-scale project compared to the other two, the Turkish and Italian schemes were both extensive (scale) and intensive (time). This was due to the uneven power of the political regimes in these three countries, in terms of their ability to raise funds, organise manpower and deploy all of these within the territory to be transformed. The Italian and Turkish regimes, which had gained and established firm political control in their countries, were in a much better position to do so than the regime in Romania, where the political scene had been much more fragile and unstable. King Carol's authoritarianism was far from creating a strong state in 1938 , a fact that was proven by the short-lived nature of his rule. ${ }^{44}$

In this context, the village of Dioști represented a mere pilot for a wider rural planning scheme that never really took off. The comparison with the other two more prominent cases does however bring out the wider implications and meaning of the project and of Romanian efforts to modernise the countryside. Like its counterparts, Dioști represented a prototype of rural modernisation with high display value. This involved a triple visibility: as a flagship project of King Carol II's new regime, as a model of ex-

43 DeGrazia, Politics of Leisure.

44 I. Scurtu, Istoria românilor în timpul celor trei regi. Carol al II-Lea, Bucharest 2010. 
pertise in the growing international field of social reform and as a way to educate the locals in aesthetic, moral and social ways. Also like the other two examples, Dioști combined the desire to transform and to preserve rural life.

Despite these differences, all three examples of rural planning were products of a similar process by which the state as an entity was expanding into the rural world, becoming involved in managing the lives of its rural citizens. On a more abstract level, the expansion of the state went hand in hand with what Lutz Raphael has called the «scientisation of the social», that is, the transformation of everyday lives of normal people into an area of professional expertise and into an important domain to be managed and improved by experts. ${ }^{45}$ In all the countries discussed above, experts from different domains (be it architecture, planning, social sciences, and others) contributed to the transformation of rural life into an object that could be planned according to scientific rules and aesthetic principles. Rural planning in fact allowed experts from peripheral countries like Turkey and Romania to distinguish themselves just as much as it allowed those in a more «central» country like Italy. This shows the rural world as a space for experimentation with new technologies, forms and norms of living more generally. Without offering eccentric or alternative lifestyles, the planned rural communities in Italy, Turkey and Romania were similar attempts to invent a new rural way of life that would allow the transition of the countryside into the modern world. The use of models, especially in the Romanian and Turkish cases, embodied the interwar vision of modernity whose drive for transformation was caught between the desire to preserve and to change the countryside.

45 L. Raphael, «Embedding the Human and Social Sciences in Western Societies, I880-I980: Reflections on Trends and Methods of Current Research», in: K. Brückweh et al. (eds.) Engineering
Society: The Role of the Human and Social Sciences in Modern Societies: 1880-1980, Basingstoke 2012, $4 \mathrm{I}-56$. 


\section{Lessons For Modern Living:}

Planned Rural Communities in Interwar Romania, Turkey and Italy

The desire to modernise the rural world was a defining feature of the period between the two World Wars. The combination of modernisation in the guise of «development», and national state-building ideology, formed a unique vision of modernity specific to the interwar period. This article compares three instances of rural planning in three countries - in Romania, Turkey and Italy - in order to understand whether or not common traits of this underlying vision of rural modernity existed beyond their respective political, social and economic differences. This comparison also serves to shed more light on the wider implications of rural planning in the interwar period.

Raluca Mușat

Department of History

Goldsmiths

University of London

UK-London SE14 6NW

e-mail: ralumusat@yahoo.com 